Florida International University FIU Digital Commons

$11-15-2013$

\title{
Recreational Angler Perspectives of Nonnative Fish Species and Mercury Advisories
}

Christopher J. Edwards

Florida International University, cedwa008@fiu.edu

DOI: $10.25148 /$ etd.FI13121205

Follow this and additional works at: https://digitalcommons.fiu.edu/etd

Part of the Environmental Health Commons, Environmental Health and Protection Commons, Natural Resources and Conservation Commons, Natural Resources Management and Policy Commons, and the Water Resource Management Commons

\section{Recommended Citation}

Edwards, Christopher J., "Recreational Angler Perspectives of Nonnative Fish Species and Mercury Advisories" (2013). FIU Electronic Theses and Dissertations. 1035.

https://digitalcommons.fiu.edu/etd/1035

This work is brought to you for free and open access by the University Graduate School at FIU Digital Commons. It has been accepted for inclusion in FIU Electronic Theses and Dissertations by an authorized administrator of FIU Digital Commons. For more information, please contact dcc@fiu.edu. 


\section{FLORIDA INTERNATIONAL UNIVERSITY \\ Miami, Florida}

\section{RECREATIONAL ANGLER PERSEPECTIVES ON NONNATIVE FISH SPECIES AND MERCURY ADVISORIES}

A thesis submitted in partial fulfillment of

the requirements for the degree of

MASTER OF SCIENCE

in

ENVIRONMENTAL STUDIES

by

Christopher J. Edwards 
To: Kenneth G. Furton

College of Arts and Sciences

This thesis, written by Christopher J. Edwards, and entitled Recreational Angler Perspectives on Nonnative Fish Species and Mercury Advisories, having been approved in respect to style and intellectual content, is referred to you for judgment.

We have read this thesis and recommend that it be approved.

Mahadev Bhat

Joel Heinen, Co-Major Professor

Jennifer Rehage, Co-Major Professor

Date of Defense: November 15, 2013

The thesis of Christopher J. Edwards is approved.

Dean Kenneth G. Furton

College of Arts and Sciences

Dean Lakshmi N. Reddi

University Graduate School

Florida International University, 2013 


\begin{abstract}
OF THE THESIS
RECREATIONAL ANGLER PERSPECTIVES OF NONNATIVE FISH SPECIES

AND MERCURY ADVISORIES

by
\end{abstract}

Christopher J. Edwards

Florida International University, 2013

Miami, Florida

\title{
Professor Jennifer Rehage, Co-Major Professor \\ Professor Joel Heinen, Co-Major Professor
}

The central Everglades serve as a Wildlife Management Area and as a Water Conservation Area for the Miami-Fort Lauderdale metropolitan area. It is also home to over 22 nonnative freshwater fish species and carries restrictive fish consumption guidelines for Mercury. In my study, boat anglers and canal bank anglers were personally interviewed in the field, to research their awareness and perspectives of these potential environmental and health threats. The study found $78 \%$ of anglers were aware of the presence of nonnative fish species, but favored native fish species, and that $69 \%$ were aware of mercury advisories, but did not eat fewer fish because of them. Demographic characteristics were found to predict awareness, which differed significantly between angler types. Public awareness campaigns of nonnative fish impacts should target high school educated, canal bank anglers while mercury advisories should be directed at canal bank anglers, who typically keep and consume their catch more than boat anglers, to those who live more than 30 miles from the area, and all anglers under the age of 48. 


\section{TABLE OF CONTENTS}

CHAPTER

PAGE

CHAPTER 1 Recreational Angler Perspectives on Noonnative Fish Species ................. 1

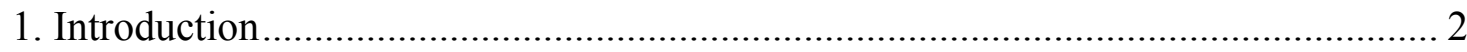

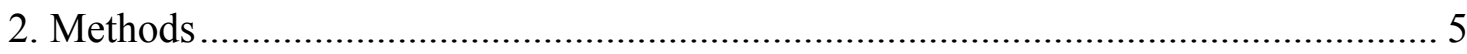

2.1 Sample selection and survey design ........................................................ 5

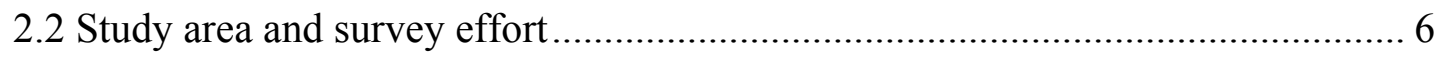

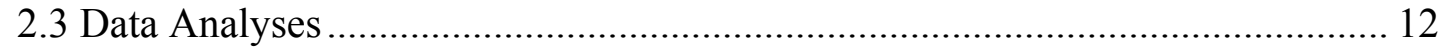

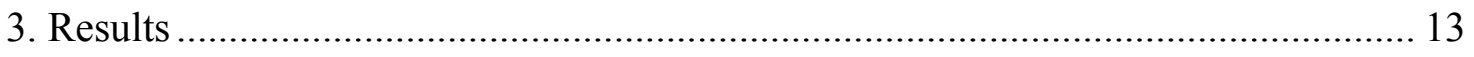

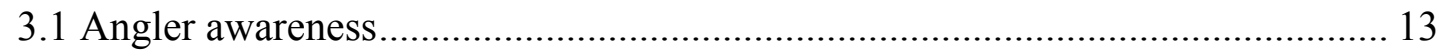

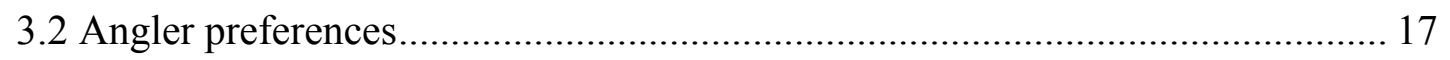

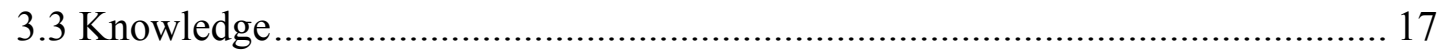

3.4 Perception of the importance of native species ................................................ 20

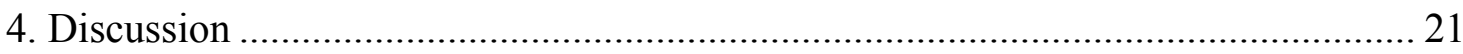

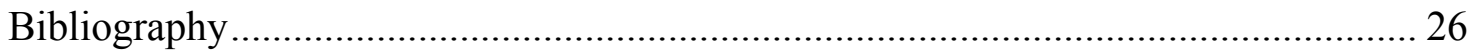

CHAPTER 2 Recreational Angler Perspectives on Mercury Advisories ....................... 30

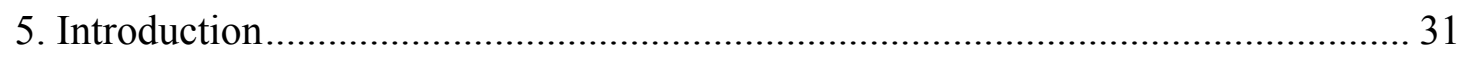

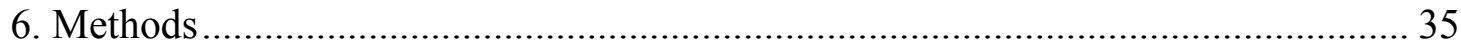

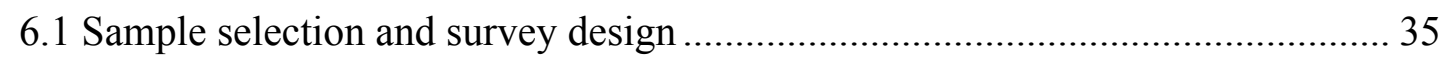

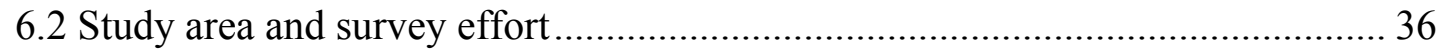

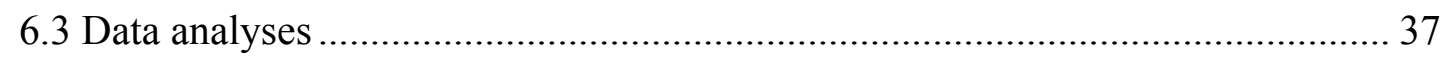

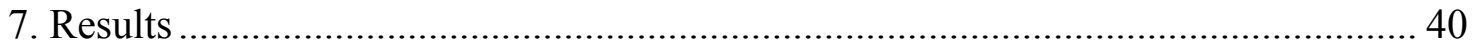

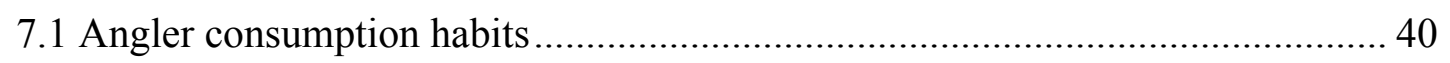

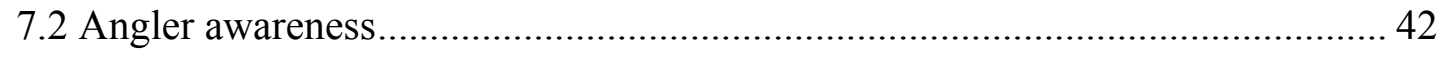

7.3 Perception of the importance of improved water quality ................................. 44

7.4 Angler perspectives of mercury advisories .................................................. 46

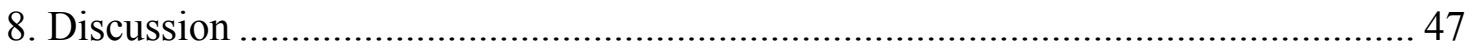

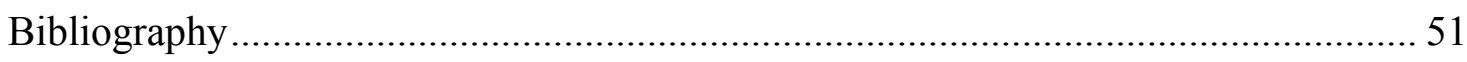

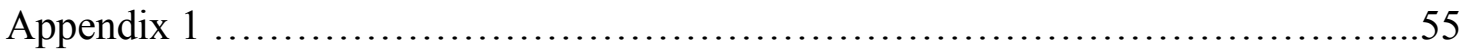




\section{LIST OF TABLES}

TABLE

PAGE

Table 1: Means, standard errors and frequencies of selected demographic characteristics of the entire sample of respondents and angler types (canal bank vs. boat anglers)

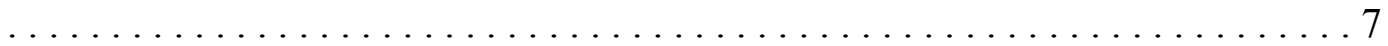

Table 2: Effort allocation and efficiency $\ldots \ldots \ldots \ldots \ldots \ldots \ldots \ldots \ldots \ldots \ldots \ldots \ldots \ldots \ldots \ldots \ldots$

Table 3: Variables used in regression analyses for awareness of nonnative fish species .11

Table 4: Logistic regression model for nonnative species awareness among all sample

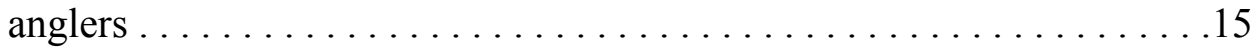

Table 5: Logistic regression model for nonnative species awareness among canal bank

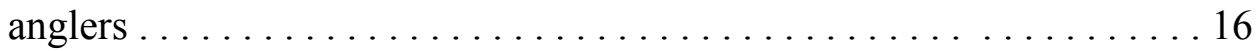

Table 6: Logistic regression model for nonnative species awareness among boat

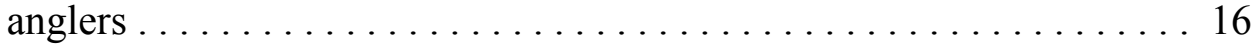

Table 7: Angler opinions of nonnative fish species $\ldots \ldots \ldots \ldots \ldots \ldots \ldots$

Table 8: Variables used in regression analyses for awareness of mercury advisories . . 39

Table 9: Fishing and consumption habits of anglers $\ldots \ldots \ldots \ldots \ldots \ldots \ldots \ldots \ldots$

Table 10: Logistic regression model for mercury advisory awareness among all sample

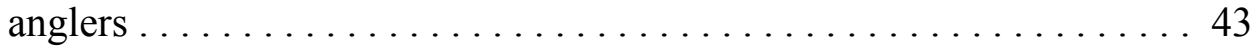

Table 11: Logistic regression model for mercury advisory awareness among canal bank

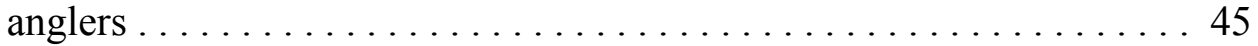


CHAPTER 1

RECREATIONAL ANGLER PERSPECTIVES OF NONNATIVE FISH SPECIES 


\section{Introduction}

Increased human disturbance, travel and commerce across the globe continue to provide pathways for both intentional and unintentional species introductions. For instance, the first introduction of a freshwater fish species to the United States was the goldfish over two hundred years ago, brought as an ornamental pet (Nico \& Fuller, 1999). More desirable nonnative fish species followed, introduced by anglers for sport and food and with significant benefits to local economies (Rahel, 2000, Pine, et al., 2007). At the same time, fish introductions have resulted in negative impacts on invaded ecosystems and native biodiversity as nonnative fishes compete and/or exploit native species (Charles \& Dukes, 2006, Crowl, et al., 2008, Simberloff, 2013). In the United States, $53 \%$ of native fish species are imperiled by introduced nonnative freshwater fish (Wilcove, et al., 1998). These introductions can also have negative impacts on recreational fisheries (Hrabik, et al., 2001, Ayala, et al., 2007). Nonnative fish are estimated to cause up to one billion dollars in damage to the US economy per year (Pimentel, et al., 2000). These invasions have also resulted is the homogenization of fish biotas across the US and the world through decreasing native species and the proliferation of adaptive nonnative species (Charles \& Dukes, 2006, Light \& Marchetti, 2007, Mitchell \& Knouft, 2009). For example, at least 58\% of watersheds in the contiguous United States have 10 or more established nonnative fish species (Heinz III, 2008).

Although fish invasions have important human dimensions, research on public attitudes toward fish invasions is lacking. Surveys of stakeholders can provide valuable information concerning their knowledge and opinions, which may be crucial to successful 
invasive species management (Larson, et al., 2011, Liu, et al., 2011). For instance, social awareness to the presence of nonnative species can be a tool in the prevention of unintentional introductions of nuisance species (Nuñez \& Pauchard, 2010). Surveys of recreational anglers in the US have shown awareness can play a role in limiting the dispersal of nonnative species (Gates et al., 2009, Kilian et al., 2012). Eisworth, et al., (2011) showed that individuals are more likely to be aware of aquatic invasive species if they are active participants in water-based recreation. A recent survey of anglers, conservationists and the general public in the United Kingdom, found that despite ignorance of the threat of nonnative species, $66 \%$ of respondents agreed that it was unacceptable to lose biodiversity (Worthington, et al., 2010). Public awareness campaigns on environmental issues are often complicated by political atmosphere, conflicting ecological expertise and well-represented special interest groups (Carpenter \& Gunderson, 2001). Effective communication to stakeholders can reduce uncertainty associated with this information and increase participation in invasive species management objectives (Liu, et al., 2011).

The state of Florida has the second highest number of established nonnative species in the United States, second only to California (Pimentel, 2004). Florida is also recognized as 'The Fishing Capital of the World' (FWC, 2013), in part because it provides 46.3 million days of recreational fishing per year, 4.4 million of those to nonresidents, more than any other state in each category (US Fish and Wildlife Service, 2008). Florida also leads all states in revenue generated from recreational angler expenditures with $\$ 4.4$ billion, which generates $\$ 441$ million in taxes (US Fish and Wildlife Service, 2008). While Everglades freshwater angling targets native largemouth 
bass (Micropterus salmoides) more than twice as frequently as any other freshwater species (Fedler, 2009), the freshwater fish fauna of the region presently includes new nonnative fishes, whose recreational value is not well understood. There are at least 22 nonnative freshwater species reproducing in the Everglades ecosystem (ECISMA, 2013). Among them, intentionally introduced Peacock Bass (Cichla ocellaris), along with other common nonnative cichlids, Oscar (Astronotus ocellatus), Mayan Cichlid (Cichlasoma urophthalmus), and Spotted Tilapia (Tilapia mariae) are part of a new recreational Everglades fisheries (FWC, 2013b). Recreational fishing in the Everglades accounts for $21 \%$ of the state's angling effort, which contributes $\$ 352.5$ million of economic impact (Fedler, 2009). However, despite the importance of recreational fishing in the Everglades and its high number of species invasions, we know little of the awareness and value of nonnative fishes among recreational anglers.

The objective of this study was to survey recreational Everglades freshwater anglers in to better understand their (1) awareness of nonnative fish species, (2) preferences and opinions of nonnative fish species, (3) scientific literacy, and (4) attitudes concerning conservation of native fish diversity. I assessed angler awareness and values using a semi-structured survey, which allows for personal opinions and conversation that cannot be captured in multiple choice formats alone, and can provide a wealth of information (Heinen, 2010). Surveys targeted both boat and land-based anglers fishing in canals in the central Everglades. I hypothesized that Everglades recreational anglers would prefer to target native fish species, instead of nonnative species and that their awareness of the presence of nonnative fish species in the fishery is high. I predicted that awareness of nonnative fish species would vary across angler type and that opinions of 
them would be mostly negative. I also expected that support for native species conservation would be high among angler groups.

\section{Methods}

\subsection{Sample selection and survey design}

My study was conducted through on-site semi-structured surveys that were pretested with the same recreational angler population at the study sites. Potential participants were asked if they fished at the location, if they were 18 years of age or older, and if they would be willing to participate in a short non-identifying survey, and selected if they answered affirmatively to all three questions. Anglers were also asked for consent to make an audio recording of the survey for quality control, and often agreed. Interviews typically took 10 minutes to complete. The same anglers were frequently encountered but were only interviewed once. Approximately 5\% of anglers encountered refused the survey, primarily because they were focused on catching fish or because they came to be alone. Interviews were conducted in English or Spanish, depending on the angler's preference. After the interview was complete, participants were given a copy of the FWC's brochure 'Exotic Fish of South Florida.' All interviews were conducted by the same individual.

The survey (Appendix 1) was designed around four sections. The first section was composed of a series of 14-19 questions (depending on responses to questions 2, 5, 7, \& 16) concerning history at the location, fishing practices, angler motivations, fishing preferences and consumption habits. The second section was comprised of 5-8 questions

(depending on responses to questions $21,23 \& 25$ ) concerning the angler's awareness and 
opinions of the presence of nonnative fish species and their knowledge of scientific terminology concerning species origin. The third section was comprised of 2 to 4 questions (depending on season) soliciting the angler's level of agreement with a series of statements concerning the conservation of native fish species. The fourth section of the interview was a card given to the angler requesting basic demographic information to analyze sample and subsample demographic characteristics (Table 1).

\subsection{Study area and survey effort}

The present day Everglades fishery is comprised of an intricately crafted drainage system, a web of canals that provides access to a thriving sport fishery for recreational anglers that includes the native largemouth bass (Gibson, 2006, FWC, 2013). Two popular canal fishing locations were targeted for the angler survey bordering the highly managed Water Conservation Area-3A (WCA-3A), in the central Everglades (Figure 1). Human-made canals and natural marshes in the region constitute part of a Wildlife Management Area (WMA) which allows fishing, hunting, and other outdoor recreation activities while sustaining habitat for native wildlife (FWC, 2013), and is managed by the Florida Fish and Wildlife Conservation Commission (FWC), in cooperation with the South Florida Water Management District (SFWMD) which operates the canals, levees, water control structures and access roads. Location 1 is a twenty-two mile stretch of canal bank running parallel to the L-29 canal, and Tamiami Trail (US 41), which serves as the main corridor between the east and west coasts of south Florida. The canal also compartmentalizes the area of the Everglades, separating WCA-3A to the north and Everglades National Park (ENP) to the south. Location 2 is Everglades Holiday Park west 
Table 1: Means, standard errors and frequencies of selected demographic characteristics of the entire sample of respondents and angler types (canal bank vs. boat anglers)

\begin{tabular}{|c|c|c|c|}
\hline Variables & Sample & Canal bank & Boat \\
\hline \multicolumn{4}{|l|}{$\operatorname{Sex}$} \\
\hline Male & $91.3 \%$ & $89.5 \%$ & $94.4 \%$ \\
\hline Female & $8.7 \%$ & $10.5 \%$ & $5.6 \%$ \\
\hline Age & $45.6 \pm 0.9$ & $44.9 \pm 1.1$ & $46.9 \pm 1.3$ \\
\hline $18-27$ & $17.5 \%$ & $19.7 \%$ & $13.5 \%$ \\
\hline $28-37$ & $15.5 \%$ & $16.2 \%$ & $14.3 \%$ \\
\hline $38-47$ & $21.7 \%$ & $21.4 \%$ & $22.2 \%$ \\
\hline $48-57$ & $19.2 \%$ & $17.0 \%$ & $23.0 \%$ \\
\hline $58-67$ & $17.2 \%$ & $14.8 \%$ & $21.4 \%$ \\
\hline 68 and older & $9.0 \%$ & $10.9 \%$ & $5.6 \%$ \\
\hline \multicolumn{4}{|l|}{ Total household Income } \\
\hline Less than $\$ 20,000$ & $18.6 \%$ & $26.2 \%$ & $4.8 \%$ \\
\hline$\$ 20,000-\$ 39,999$ & $21.1 \%$ & $26.6 \%$ & $11.1 \%$ \\
\hline$\$ 40,000-\$ 59,999$ & $21.1 \%$ & $21.4 \%$ & $20.6 \%$ \\
\hline$\$ 60,000$ or more & $39.2 \%$ & $25.8 \%$ & $63.5 \%$ \\
\hline \multicolumn{4}{|l|}{ Education attained } \\
\hline Less than high school or GED & $7.9 \%$ & $10.9 \%$ & $2.4 \%$ \\
\hline High school or GED & $38.9 \%$ & $41.5 \%$ & $34.1 \%$ \\
\hline Some college & $28.7 \%$ & $25.8 \%$ & $34.1 \%$ \\
\hline Bachelor's degree or higher & $24.5 \%$ & $21.8 \%$ & $29.4 \%$ \\
\hline \multicolumn{4}{|l|}{ Household size } \\
\hline Total & $3.0 \pm 0.8$ & $3.2 \pm 0.1$ & $2.7 \pm 0.1$ \\
\hline Adults & $2.4 \pm 0.5$ & $2.5 \pm 0.07$ & $2.1 \pm 0.06$ \\
\hline Children under 18 & $0.7 \pm 0.6$ & $0.7 \pm 0.08$ & $0.6 \pm 0.08$ \\
\hline
\end{tabular}


Figure 1 Map of survey locations

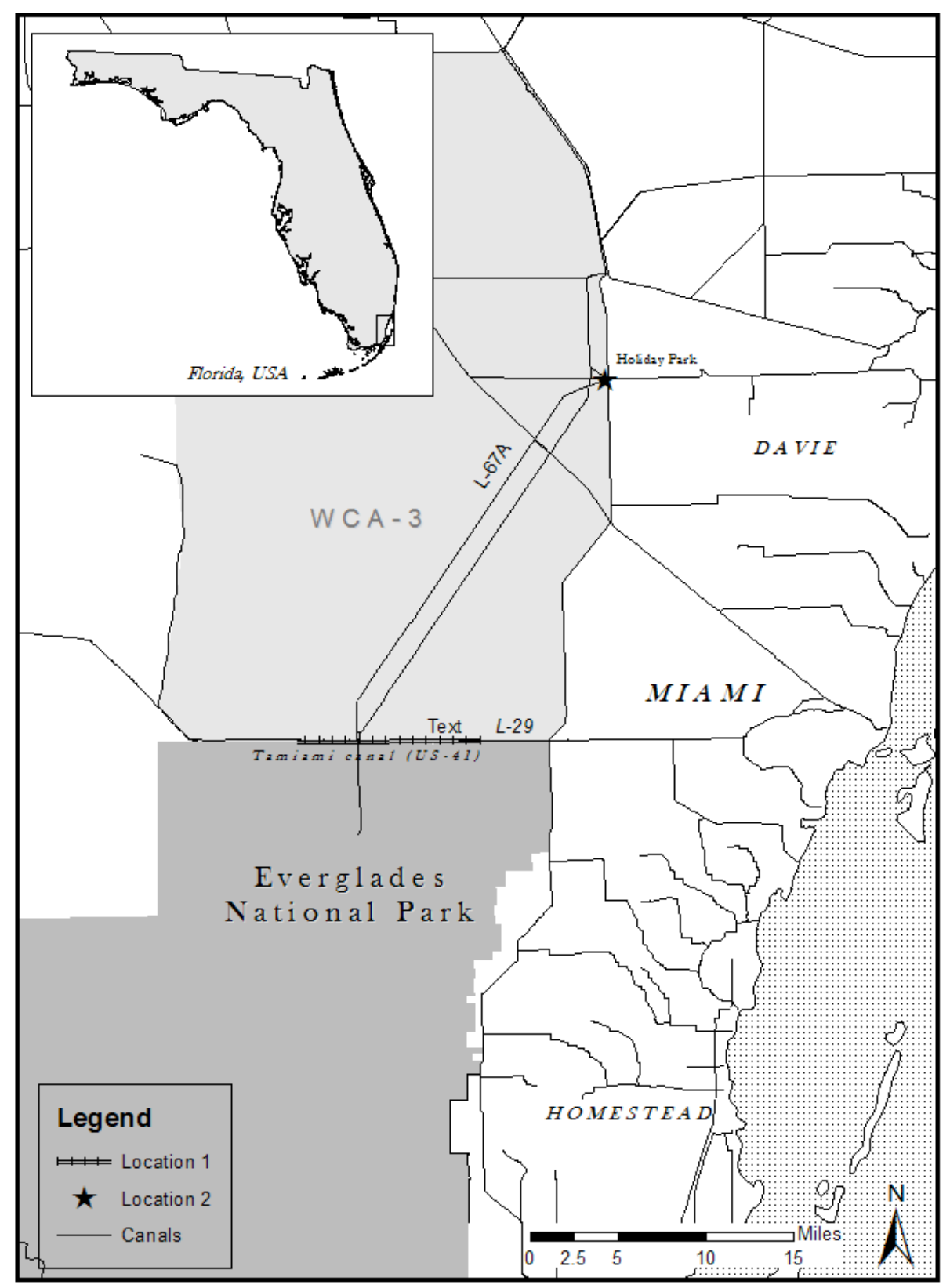


of Fort Lauderdale, Florida. Everglades National Park is an iconic public recreational area, complete with an airboat tour company and alligator wrestling show, previously leased from Broward County by the FWC, and designated a county park in 2013 . The location was chosen because of its four public boat ramps which provide access to the L67A canal, one of the best bass angling locations in the state of Florida (FWC, 2013), and it connects to the L-29 canal at the southern end. These locations 1 and 2 were chosen because of the high volume of anglers who fish from the canal levees and from boats respectively.

The survey was conducted year-round from May 6th, 2012 to May 4th, 2013 and effort was allocated into 13 consecutive 28-day periods ( 8 wet season periods and 5 dry season periods, Table 2). Each dry season sampling period consisted of three week days and two weekend days (non-holiday) of sampling. To compensate for the lower number of respondents in the wet season when angling effort is lower (B. Moody pers. comm.) the number of survey days in wet season periods were doubled to six week days and four weekend days. Every survey day had a morning shift between 8:00 am and 12:00 pm and an afternoon shift from 2:00 pm to 6:00 pm. Study locations alternated within the day, and starting locations alternated between days (within separate week day and weekend day sample framework) to allocate equal sampling effort spatially and temporally. Scheduled survey days were at times cancelled because of poor weather conditions. Bank anglers were recruited at location 1 (L-29 canal) by visually scanning canal banks from a vehicle and approaching everyone fishing. Boat anglers at location 2 (Holiday Park) were approached at boat ramps after and before returning from their fishing trips (Table 2). 
Table 2: Effort allocation and efficiency

\begin{tabular}{|c|c|c|c|c|c|}
\hline & \multicolumn{2}{|c|}{ Wet season } & \multicolumn{2}{|c|}{ Dry Season } & Total \\
\hline Boat anglers surveys & \multicolumn{2}{|c|}{62} & \multicolumn{2}{|c|}{59} & 121 \\
\hline Canal bank anglers & \multicolumn{2}{|c|}{152} & \multicolumn{2}{|c|}{82} & 234 \\
\hline Total surveys & \multicolumn{2}{|c|}{214} & \multicolumn{2}{|c|}{141} & 355 \\
\hline Distribution: & $n$ & \#/hour & $n$ & \#/hour & \\
\hline Weekday & 108 & 0.37 & 77 & 0.80 & 185 \\
\hline Weekend day & 106 & 0.70 & 64 & 1.00 & 170 \\
\hline AM & 119 & 0.37 & 57 & 0.71 & 176 \\
\hline PM & 95 & 0.30 & 84 & 1.05 & 179 \\
\hline Location 1 & 152 & 0.48 & 82 & 1.03 & 234 \\
\hline Location 2 & 62 & 0.19 & 59 & 0.74 & 121 \\
\hline
\end{tabular}


Table 3: Variables used in regression analyses for awareness of nonnative fish species

\begin{tabular}{|c|c|c|}
\hline Variable & Description & Variable type \\
\hline Experience & Years of fishing experience at location & Continuous \\
\hline Frequency & Average number of fishing days/month & Continuous \\
\hline Recreation & Angler fishes for recreation & Categorical \\
\hline Sport & Angler fishes for sport & Categorical \\
\hline Food & Angler fishes for food & Categorical \\
\hline \multirow[t]{4}{*}{ Distance } & Less than 10 miles from home & Categorical \\
\hline & 10 to 20 miles from home & \\
\hline & 20 to 30 miles from & \\
\hline & More than 30 miles from home & \\
\hline \multirow[t]{2}{*}{ Gender } & Male & Categorical \\
\hline & Female & \\
\hline \multirow[t]{6}{*}{ Age } & $18-27$ & Categorical \\
\hline & $28-37$ & \\
\hline & $38-47$ & \\
\hline & $48-57$ & \\
\hline & $58-67$ & \\
\hline & 68 and older & \\
\hline \multirow[t]{4}{*}{ Education } & Less than high school or GED & Categorical \\
\hline & High school or GED & \\
\hline & Some college & \\
\hline & Bachelor's degree or higher & \\
\hline \multirow[t]{4}{*}{$\begin{array}{l}\text { Total household } \\
\text { income }\end{array}$} & Less than $\$ 20,000$ & Categorical \\
\hline & $\$ 20,000-\$ 39,999$ & \\
\hline & $\$ 40,000-\$ 59,999$ & \\
\hline & $\$ 60,000$ or more & \\
\hline \multirow[t]{7}{*}{ Household size } & One & Categorical \\
\hline & Two & \\
\hline & Three & \\
\hline & Four & \\
\hline & Five & \\
\hline & Six & \\
\hline & More than six & \\
\hline \multirow[t]{2}{*}{ Angler type } & Canal bank & Categorical \\
\hline & Boat & \\
\hline Club membership & Angler belongs to a fishing club & Categorical \\
\hline
\end{tabular}




\subsection{Data Analyses}

I used a backwards stepwise logistic regression to examine how independent variables such as anglers' characteristics and demographic traits can predict angler awareness of the nonnative fish presence for all respondents and each angler type independently (Table 3). For each categorical variable, levels of increasing education, income, age group, household size and distance were coded to be compared to a reference level (the first level) of the variable (simple coding). Simple coding is similar to dummy coding, in which a $0 / 1$ categorical variable (dummy variable) is compared. A small number of anglers opted not to complete the demographic card in its entirety, leaving blank values for total household income $(n=25)$, zip code $(n=16)$ and education $(n=$ 12). Deleting cases with missing values may cause bias (Scheffer, 2002). A common statistical software method used to avoid losing valuable information is to impute the data with the mean or mode (Scheffer, 2002). Missing continuous data for the variables age, household size, and distance (calculated from zipcode, using GIS 10.0) were imputed by taking the mean of the sample variable. Missing categorical data such as income and education were imputed by taking the modes of the sample variables. The HosmerLemeshow test of goodness of fit was applied to the resulting logistic regression models.

I wanted to determine if anglers preferred native fish species over exotic species. In order to adjust for anglers who were not familiar with the distinction between native and nonnative, responses to questions about target species and favorite species (questions 13 \& 14) were categorized into only native, only nonnative, both, and anything if no specific species was named. Pearson's chi-square tests were run on cross-tabulated distributions to see if angler groups differed in their responses for this question and 
others. I also wanted to see if anglers had opinions about nonnative fish species. Responses to question 27 concerning opinions on nonnatives were scored as either no opinion, only positive, only negative, and positive and negative. I wanted to see if anglers were knowledgeable of scientific terminology used in describing origins of species. After asking if anglers were familiar with the terminology in questions $21-25$, anglers were asked to give explanations of the words native, nonnative, and invasive. Responses were considered accurate if the angler identified native species as 'from here', nonnative species as 'not from here' and invasive species as 'not from here and causes some kind of harm or damage'. I also wanted to see if anglers thought it was important to conserve native diversity for themselves or for future generations through questions requiring the respondent to choose their level of agreement with a statement using a 5 point rating scale with options of strongly agree (=5), somewhat agree $(=4)$, neutral $(=3)$, somewhat disagree $(=2)$ and strongly disagree $(=1)$. The Mann-Whitney $\mathrm{U}$ test was performed to test for a difference in distribution of responses 1) between each question, to compare present and future use values, 2) between seasons to find if hearing an informational brief influenced strength in agreement, and 3) between angler types. All analyses were completed using IBM SPSS Statistics for Windows, version 20.0.

\section{Results}

\subsection{Angler awareness}

The majority of respondents (78.6\%) were aware of a non-native fish presence in the fishery. After adjusting for other variables in the logistic regression model, advisory awareness was significantly associated with years of fishing experience, fishing frequency, boat anglers, higher education and small household size (Table 4). Boat 
anglers were 2.4 times more likely to be aware of the presence of non-native fish than canal bank anglers. An angler with a bachelor's degree or higher was 5.8 times as likely to be aware as an angler with less than a high school education. Anglers from smaller households (1-2) were more aware of nonnative species than households of 3 more. The Hosmer-Lemeshow goodness of fit test found no difference between the model-predicted and observed values $\left(\chi^{2}=11.643, d f=8, p=0.168\right)$.

Surveyed boat anglers claimed to be aware $90.5 \%$ of the time compared to $72.1 \%$ of canal bank anglers $\left(\chi^{2}=16.397, d f=1, p<0.001\right)$. Using the same input variables, removing the variable Angler type, regression models were produced for awareness of canal bank and boat anglers. After adjusting for other variables in the logistic regression model, advisory awareness among canal bank anglers was significantly associated with years of fishing experience, fishing frequency, higher education and fishing for recreation (Table 5). The negative coefficient of the variable Recreation indicates that fishing for recreation decreases probability of awareness, with an odds ratio of 0.54 , to that of angler who did not select recreation as their reason for fishing. The Hosmer-Lemeshow goodness of fit test found no difference between the model-predicted and observed values $\left(\chi^{2}=8.029, d f=8, p=0.431\right)$.

Awareness among boat anglers was significantly associated with gender, education and household size (Table 6). Males were 38.5 times more likely to be aware than females and anglers with a bachelor's degree or higher were 17.8 times more likely to be aware than someone with a high school education or less. Smaller households, with one or two people, were more than 5 times as likely to be aware than households larger 
Table 4: Logistic regression model for nonnative species awareness among all sample anglers

\begin{tabular}{lcccc}
\hline Characteristic & $\boldsymbol{\beta}$ & Odds Ratio & CI & p-value \\
\hline $\begin{array}{l}\text { Angler type } \\
\text { Canal bank }\end{array}$ & & Reference & - & \\
Boat & 0.92 & 2.5 & $1.3-5.0$ & $\mathbf{0 . 0 0 9}$ \\
$\begin{array}{l}\text { Frequency } \\
\text { (Average trips/month) }\end{array}$ & 0.16 & 1.2 & $1.0-1.4$ & $\mathbf{0 . 0 2}$ \\
$\begin{array}{l}\text { Experience } \\
\text { (Years) }\end{array}$ & 0.027 & 1.03 & $1.01-1.05$ & $\mathbf{0 . 0 0 5}$ \\
$\begin{array}{l}\text { Education } \\
\text { Less than high school or GED }\end{array}$ & & & & \\
High school or GED & 0.89 & 2.4 & $1.0-6.2$ & 0.06 \\
Some college & 1.5 & 4.3 & $1.6-11.8$ & $\mathbf{0 . 0 0 5}$ \\
Bachelor's degree or higher & 1.7 & 5.5 & $1.9-15.9$ & $\mathbf{0 . 0 0 2}$ \\
& & & & \\
p values $<.05$ in bold & & & &
\end{tabular}


Table 5: Logistic regression model for nonnative species awareness among canal bank anglers

\begin{tabular}{lcccc}
\hline Characteristic & $\boldsymbol{\beta}$ & Odds Ratio & CI & $\boldsymbol{p}$-value \\
\hline $\begin{array}{l}\text { Frequency } \\
\text { (Average trips/month) }\end{array}$ & 0.33 & 1.4 & $1.1-1.7$ & $\mathbf{0 . 0 0 1}$ \\
$\begin{array}{l}\text { Experience } \\
\text { (Years) }\end{array}$ & 0.026 & 1.03 & $1.01-1.05$ & $\mathbf{0 . 0 1 5}$ \\
Education & & & & \\
Less than high school or GED & - & Reference & - & 0.051 \\
High school or GED & 0.62 & 1.9 & $0.7-5.3$ & 0.242 \\
Some college & 1.2 & 3.5 & $1.1-10.8$ & $\mathbf{0 . 0 3 3}$ \\
Bachelor's degree or higher & 1.4 & 4.2 & $1.3-13.5$ & $\mathbf{0 . 0 1 7}$ \\
& & & & \\
Significance at $\alpha=.05$ in bold & & & & \\
CI=95\% confidence interval & & & &
\end{tabular}

Table 6: Logistic regression model for nonnative species awareness among boat anglers

\begin{tabular}{|c|c|c|c|c|}
\hline Characteristic & $\beta$ & Odds Ratio & CI & $p$-value \\
\hline Gender & \multicolumn{3}{|c|}{ Reference: female } & \\
\hline Male & 3.7 & 38.5 & $4.2-351$ & 0.001 \\
\hline \multicolumn{5}{|l|}{ Education } \\
\hline High school or less & \multicolumn{3}{|c|}{ Reference } & 0.03 \\
\hline Some college & 1.9 & 6.4 & $1.1-37$ & 0.04 \\
\hline Bachelor's degree or higher & 2.9 & 17.8 & $1.3-241$ & 0.03 \\
\hline Household size & \multicolumn{3}{|c|}{ Reference: More than 2} & \\
\hline One or two & 1.7 & 5.2 & $1.2-23$ & $\mathbf{0 . 0 3}$ \\
\hline \multicolumn{5}{|l|}{ Significance at $\alpha=.05$ in bold } \\
\hline$C I=95 \%$ confidence inter $v$ & & & & \\
\hline
\end{tabular}


than two. The Hosmer-Lemeshow goodness of fit test found no difference between the model-predicted and observed values $\left(\chi^{2}=9.982, d f=6, p=0.125\right)$.

\subsection{Angler preferences}

The majority of respondents (65.1\%) were targeting only native species, while anything was the second most frequent response by anglers (19.2\%), followed by both (12.4\%) and only nonnative (3.4\%). There was a significant difference in the distribution of listed target species $\left(\chi^{2}=26.217, d f=3, p<0.001\right)$ and listed favorite species $\left(\chi^{2}=\right.$ 12.429, $d f=3, p<0.01$ ) among angler types (Figure 2). A majority of respondents (71.8\%) named only native species as their favorite species to catch, while only nonnative species was the second most frequent response (10.4\%), followed by both $(9.6 \%)$ and anything $(8.2 \%)$.

The most commonly targeted species by all anglers was the native largemouth bass, identified as a target by $65.9 \%$ of the respondents. A total of $80.2 \%$ of boat anglers targeted largemouth bass, while $58.1 \%$ of canal bank anglers did $\left(\chi^{2}=26.217, d f=1, p<\right.$ 0.001). Of canal bank anglers, $12.7 \%$ targeted nonnative peacock bass, compared to only $4.0 \%$ of boat anglers $\left(\chi^{2}=7.096, d f=1, p=0.008\right)$.

The largemouth bass was the most commonly identified favorite fish species, named by $66.8 \%$ of the sample. The percentage of anglers who listed the largemouth bass as a favorite species also varied as function of Angler type $\left(\chi^{2}=24.176, d f=1, p<\right.$ 0.001). Boat anglers identified largemouth bass as a favorite fish species at a higher frequency than canal bank anglers, $83.3 \%$ to $57.8 \%$, respectively. 


\section{Figure 2: Frequencies of angler type preferences}
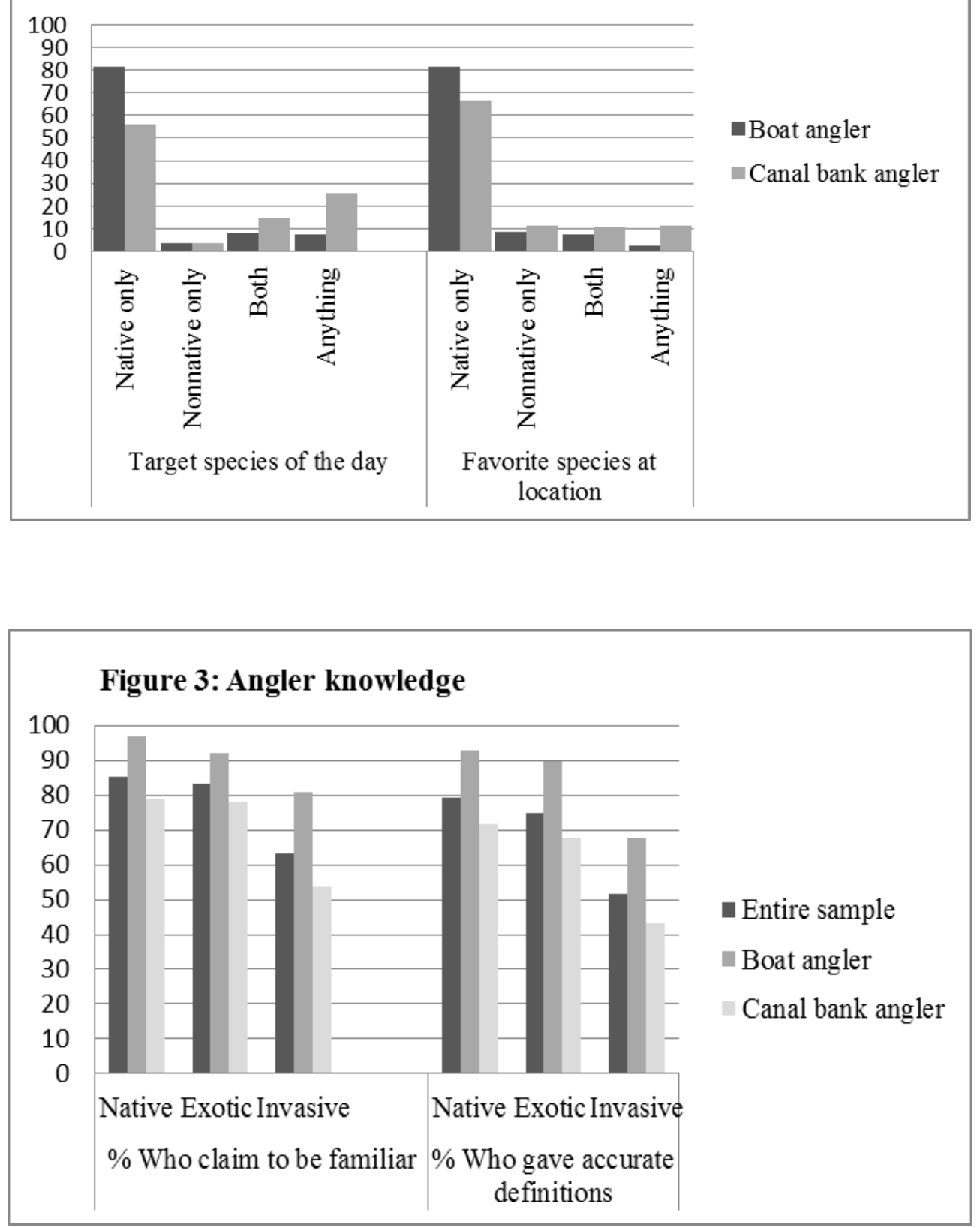
Table 7: Angler opinions of nonnative fish species

\begin{tabular}{lccc}
\hline Opinions & $\begin{array}{c}\text { All } \\
\text { respondents }\end{array}$ & $\begin{array}{c}\text { Canal bank } \\
\text { angler }\end{array}$ & $\begin{array}{c}\text { Boat } \\
\text { angler }\end{array}$ \\
\hline No opinion/neutral & $37.9 \%$ & $46.8 \%$ & $22.4 \%$ \\
Positive only & $6.7 \%$ & $6.0 \%$ & $8.0 \%$ \\
Negative only & $37.0 \%$ & $33.0 \%$ & $44.0 \%$ \\
Positive \& Negative & $18.4 \%$ & $14.2 \%$ & $25.6 \%$
\end{tabular}




\subsection{Knowledge and opinions of nonnative fish}

A majority of the sample claimed to be familiar with the terms native species, nonnative or exotic species and invasive species (Sample familiarity and accuracy is shown in Figure 3). Boat anglers were significantly more familiar with terminology and gave accurate definitions of terms more frequently ( $p$-values for all comparisons $<0.05$ ).

When anglers were asked their opinions about nonnative fishes, the most common response type was no opinion. There was a significant difference in the distribution of opinions among canal bank and boat anglers $\left(\chi^{2}=21.145, d f=3, p<0.001\right)$ (Table 7). The percentage of canal bank anglers who had no opinion was twice as high as boat anglers. Both angler groups held only positive viewpoints at low frequencies.

\subsection{Perception of the importance of native species}

A majority of anglers strongly agreed with both statements concerning native biodiversity conservation. The most common response to statement one (Management decisions that will benefit the future of native species are important to me), was strongly agree $(81.7 \%)$ followed by somewhat agree $(11.5 \%)$, neutral $(5.9 \%)$ and somewhat disagree $(0.8 \%)$. The most common response to statement two (It is important to me to conserve native species for future generations) was strongly agree (91.0\%) followed by somewhat agree (5.6\%) and neutral (2.8\%). A significantly higher percentage of the sample strongly agreed with statement two than with statement one $(p<0.001)$. There was no significant difference in the distribution of Likert scale responses to statement one $(p=0.67)$ or statement two $(p=0.052)$ between wet season anglers $(n=203)$ asked after the informational brief and dry season anglers $(n=141)$ asked before the brief. 
A significant difference $(p<0.05)$ in response frequencies was found between angler types for statement one. Boat anglers agreed with statement one at a frequency of $89.1 \%$ compared to $75.3 \%$ of canal bank anglers. There was no significant difference in agreement with statement two between angler types.

\section{Discussion}

My survey of Everglades recreational anglers showed that the majority of anglers interviewed were aware of the presence of nonnative fish species in their fishery. Boat anglers showed higher awareness of the presence of nonnative fish species than canal bank anglers, which related to a combination of socio-demographic variables. Boat anglers were more educated, had higher incomes, and fished more for sport than for other reasons (for food or for recreation). Logistic regression found that education was a significant predictor of awareness for the entire sample and for individual angler types. The variable household size was a predictor for the entire sample and boat anglers. The variables frequency and experience were common predictors for the entire sample and canal bank anglers. Gender was a strong predictor only for boat anglers.

The significant association of a college education with awareness in this study is congruent with other studies on awareness (Eisworth et al., 2011) and native species knowledge (Jacobson \& Marynowski, 1997). Although most anglers are not scientists, it is possible to assume that individuals, who seek a higher education, will educate themselves on their environment and hobbies and therefor might encounter information about nonnative fish species. Jacobson's study also found that males scored significantly higher than females on questions testing knowledge about local native species and anglers were significantly more knowledgeable than general recreational users. The 
significant difference between awareness of males and females in this study could not be attributed to a significant difference in education, frequency, or experience. The increased probability of an angler with a household size of 1-2 people over bigger household sizes may be explained by a significant difference in the experience. Boat anglers living in a household of 1-2 people had more experience, $21.2 \pm 1.8$ years, compared to boat anglers with a household of 5 or more $(8.3 \pm 2.5, F=3.512, \mathrm{df}=2, p=0.046)$.

Over half of the sample (55.4\%) included a negative comment about nonnative fish species when sharing their opinions on them. Boat anglers gave negative opinions twice as frequently as canal bank anglers, and $69 \%$ included some sort of negative comment in their response. Most negative opinions were associated with perceived negative impacts on desirable native species such as bluegill, red-eared sunfish and largemouth bass. Positive comments generally were focused on the challenge and sport of catching a peacock bass or the addition of a desirable edible species. The high number of anglers that are aware of nonnative fishes and knowledgeable on the meaning of species terminology is a positive indicator of the recreational angler community's ability to identify nonnative species and make educated decisions about transporting fish between water bodies and releasing aquarium pets.

Public awareness campaigns are an effective tool used in invasive species management to reduce the number of vectors and pathways known to introduce nonnative species (Pysek \& Richardson, 2010). A study by Garcia-Llorente in 2010, found that anglers who were unaware of the impacts of nonnative species were more willing to spread nonnative species than those who were aware. Another study by Kilian in 2012, found that the release of un-used invasive and introduced bait fish is common among 
recreational anglers who are unaware of potential impacts of invasive species.

Environmental education campaigns are often a large portion of expenses in invasive species management (Vila et al.2010) and may be more cost effective if information is targeted to stakeholders who have little knowledge of the problem and are also potential vectors. Furthermore, Bremner \& Park (2011) found that respondents, who had previously been aware of control and eradication projects, were more likely to support general wildlife control and eradication programs. The disparity in awareness between canal bank and boat anglers clearly demonstrates a greater need to direct nonnative and invasive fish species information toward canal bank anglers.

Finding differences among stakeholder groups and how to better understand their interests, environmental behaviors and personal socio-demographic characteristics can be an important tool in invasive species management (Garcia-Llorente, 2008). Stakeholder groups are often diverse and little effort is made to communicate research to the lay public (Salmi \& Salmi, 2010). Skepticism about how scientific research is applied in fisheries management can create barriers in communication of information that can prevent maximizing the information's full potential (Dedual, 2013). A study by Martin et $a l$. found that there are increasing numbers of people using internet search engines to recruit recreational fishing opportunities despite an overall decrease in angler participation (Martin et al. 2012). Placement of information about nonnative fish species on websites that report on 'fishing conditions', the top searched Google phrase associated with fishing (Martin et al. 2012), could educate anglers who use the internet and may be unaware of the presence of nonnative fishes in the fishery. A survey of the public in Scotland found television was the number one medium of information on nonnative 
species issues ( $81 \%$ of sample) (Bremner \& Park, 2007). Another study in Montana found that a majority of anglers who were aware of aquatic nuisance species were informed from reading a magazine (73\%) or newspaper (59\%) (Gates, Guy, \& Zale, 2009). Surely one medium cannot be depended on to reach all stakeholder groups. Decades of establishment by nonnative fish in South Florida have been highlighted by television, newspaper articles, and academic journals, and have also been advertised by the FWC and sport fishery tourism websites (FWC, 2013).

A study of French school children found that children were able to identify $75 \%$ of a sample of local fauna, but prioritized importance of conservation of exotic charismatic fauna over local species, and drew their knowledge from media such as television and the internet (Ballouard et al. 2011). It is widely recognized that attractive and emotionally appealing animals receive wide conservation support (Jacobson \& Marynowski, 1997), however my study found strong support for conservation of less attractive, but highly utilized, native fish species. Similar to the results by Jacobson, support for native species conservation (questions $30 \& 31$ ) did not differ among levels of education attainment or income. With such high numbers choosing strongly agree, the only difference of consequence was the significant difference between the entire sample's agreement with statements one and two. The sample's stronger agreement with a statement referring to the importance of native species for future generations over a statement that implies benefits that could possibly be realized by the individual, shows that the principle of conservation is important to many stakeholders. Kil's study (2010) of visitors to Ocala National Forest found that more direct interactions (frequency) or longer physical experiences (experience) in natural environments fosters place-attachment with 
natural environments. Higher attached visitors perceived high enjoyment from natural areas and wildlife and desired benefits related to scenery, escape from physical and social pressure and nostalgia (Kil, Holland, \& Stein, 2010). Anglers in my study may also have high place attachment which is being reflected in their ideal vision of a future Everglades. It is important to study the perspectives of Everglades recreational anglers because of the regions high utility for outdoor recreation and the diverse groups of stakeholders living in close proximity. My data collected from stakeholders can be used by the FWC in fishery management objectives and as the impetus of stakeholder support for biodiversity conservation efforts and nonnative fish control programs. Anglers have been known to illegally transport desirable fish species between water bodies and may do so without knowledge about their potential to harm the integrity of native fish populations. Environmental education is vital in forming support for conservation of native species diversity (Martin, 2012). Targeting stakeholder groups with understandable information has the potential to educate the public on the known risks to native species diversity and ecosystem functions that are associated with nonnative species introductions. Although it is impossible to predict the cumulative impacts that nonnative fishes may have on the Everglades in the future, allowing stakeholders to be more conscious of those possibilities could potentially prevent some anglers from being 'part of the problem'. 


\section{Bibliography}

Ayala, J., Rader, R., \& Belk, M. (2007). Ground-truthing the impact of invasive species: Spatio-temporal overlap between native least chub and introudced western mosquitofish. Biological Invasions, 857-869.

Ballouard, J. M., Brischoux, F., \& Bonnet, X. (2011). Children prioritize virtual exotic biodiversity over local biodiversity. Plos One.

Bremner, A., \& Park, K. (2007). Public attitudes to the management of invasive nonnative species in Scotland. Biological Conservation, 306-314.

Carpenter, S., \& Gunderson, L. (2001). Coping with Collapse: Ecological and Socal Dynamics in Ecosystem Management. BioScience, 451-457.

Charles, H., \& Dukes, J. (2006). Impacts of Invasive Species on Ecosystem Services. In W. Nentwig, Biological Invasions (pp. 217-237). Berlin: Springer.

Crowl, T., Crist, T., Parmenter, R., Belovsky, G., \& Lugo, A. (2008). The spread of invasive species and infectious disease as drivers of ecosystem change. Frontiers in Ecology and the Environment, 238-246.

Dedual, M., Sague Pla, O., Arlinghaus, R., Clarke, A., \& Ferter, K. (2013). Communication between scientists, fishery managers and recreational fishers: lessons learned from a comparative analysis of international case studies. Fisheries Management and Ecology, 234-246.

ECISMA. (2013, May 18). Everglades Cooperative Invasive Species Management Area. Retrieved from 4th Annual Everglades CISMA Non-native Fish Round Up: www.evergladescisma.org/roundup/

Eisworth, M., Yen, S., \& Kooten, G. C. (2011). Factors determining awareness and knowledge of aquatic invasive species. Ecological Economics, 1672-1679.

Fedler, T. (2009). The Economic Impact of Recreational Fishing in the Everglades Region. Key Largo: Bonefish \& Tarpon Trust.

FWC. (2006). Peacock Bass [Brochure]. Tallahassee, FL: Florida Fish and Wildlife Conservation Commission.

FWC. (2013a, September 15). Everglades Conservation Areas. Retrieved from MyFWC: http://myfwc.com/fishing/freshwater/sites-forecast/s/everglades-conservationareas/ 
FWC. (2013b, September 1). Fishing Capital of the World. Retrieved from Florida Fish and Wildlife Conservation Commision:

http://myfwc.com/fishing/freshwater/black-bass/background/fishing-capital/

FWC. (2013c, October 15). What are wildlife management areas? Retrieved from Florida Fish and Wildlife Conservation Commission:

myfwc.com/viewing/recreation/wmas/

Garcia-Llorente, M., Martin-Lopez, B., Gonzalez, J., Alcorlo, P., \& Montes, C. (2008).

Social perceptions of the impacts and benefits of invasive alien species:

Implications for management. Biological Conservation, 2969-2983.

Gates, K., Guy, C., \& Zale, A. (2009). Angler Awareness of Aquatic Nuisance Species and Potential Transport Mechanisms. Fisheries Management and Ecology, 448456.

Gibson, S. (2006, October 29). Panfish heaven; The Everglades and its canals are popular places for those who like to fish for oscars, Mayan cichlids and other species. Sarasota Herald Tribune, p. C2.

Heinen, J. (2010). The Importance of a Social Science Research Agenda in the Management of Protected Natural Areas, with Selected Examples. The New York Botanical Garden.

Heinz III, H John Center for Science, Economics, and the Environment \& Center for Resource Economics . (2008). The State of the Nation's Ecosystems: Measuring the Lands, Waters, and Living Resources of the United States. Washington D.C.: Island Press.

Hrabik, T., Carey, M., \& Webster, M. (2001). Interaction Between Young-of-the-Year Exotic Rainbow Smelt and Native Yellow Perch in a Northern Temperate Lake . Transactions of the American Fisheries Society, 568-5582.

Jacobson, S., \& Marynowski, S. (1997). Public Attitudes and Public Knowledge About Ecosystem Management on Department of Defense Land in Florida. Conservation Biology, 770-781.

Kil, N., Holland, S., \& Stein, T. (2010). Improving the management of natural resource recreation areas through understanding place-attached visitor segments. Journal of Park and Recreation Administration, 16-41.

Kilian, J., Klauda, R., Widman, S., Kashiwagi, M., Bourquin, R., Weglein, S., \& Schuster, J. (2012). An assessment of a bait industry and angler behavior as a vector of invasive species. Biological Invasions, 1469-1481. 
Larson, D., Phillips-Mao, L., Quiram, G., Sharpe, L., Stark, R., Sugita, S., \& Weiler, A. (2011). A framework for sustainable invasive species management:

Environmental, social and economic objectives . Journal of Environmental Management, 14-22.

Light, T., \& Marchetti, M. (2007). Distinguishing Between Invasions and Habitat Changes as Drivers of Diversity Loss Among California's Freshwater Fishes. Conservation Biology, 434-446.

Liu, S., Sheppard, A., Kriticos, D., \& Cook, D. (2011). Incorporating uncertainty and social values in managing invasive alien species: a deliberative multi-criteria evaluation approach. Biological Invasions, 2323-2337.

Martin, D., Pracheil, B., DeBoer, J., Wilde, G., \& Pope, K. (2012). Using the Internet to Understand Angler Behavior in the Information Age. Fisheries, 458-463.

Mitchell, A., \& Knouft, J. (2009). Non-native fishes and native species diversity in freshwater fish assemblages across the United States. Biological Invasions, 14411450 .

Nico, L., \& Fuller, P. (1999). Spatial and Temporal Patterns of Nonindigenous Fish Introductions in the United States. Fisheries, 16-27.

Nunez, M., \& Pauchard, A. (2010). Biological invasions in developing and developed countries:Does one model fit all? Biological Invasions, 707-714.

Pimentel, D. (2004). Update on the environmental and economic costs associated with alien-invasive species in the United States. Ecological Economics, 273-288.

Pimentel, D., Lach, L., Zuniga, R., \& Morrison, D. (2000). Environmental and economic costs of nonindigenous species in the United States. Bioscience, 53-65.

Pine, W., Kwak, T., \& Rice, J. (2007). Modeling Management Scenarios and the Effects of an Introduced Apex Predator on a Coastal Riverine Fish Community.

Transactions of the American Fisheries Society, 105-120.

Pysek, P., \& Richardson, D. (2010). Invasive Species, Environmental Change and Management, and Health. In Annual Review of Environment and Resources (pp. 25-55). Palo Alto, California: Annual Reviews.

Rahel, F. (2000). Homogenization of fish faunas across the United States. Science, 854856. 
Salmi, J., \& Salmi, P. (2010). Fishing tourism, biodiversity protection and regional politics in the River Tornionjoki, Finland. Fisheries Management and Ecology, 192-198.

Scheffer, J. (2002). Dealing with Missing Data. Res. Lett. Inf. Math. Sci., 153-160.

Simberloff, D. e. (2013). Impacts of biological invasions: what's what and the way forward. Trends in Ecology \& Evolution, 58-66.

US Department of the Interior, Fish and Wildlife Service and US Department of Commerce, Census Bureau. (2008). 2006 National Survey of Fishing, Hunting and Wildlife-Associated Recreation . Arlington, VA: US Fish and Wildlife Service.

Vila, M. (2010). How well do we understand the impacts of alien species on ecosystem services? A pan-European, cross taxa assessment . Frontiers in Ecology and the Environment, 135-144.

Wilcove, D., \& Bean, M. (1994). The Big Kill: declining biodiversity in America's lakes and rivers. Washington D.C.: Environmental Defense Fund.

Wilcove, D., Rothstein, D., Dubow, J., Phillips, A., \& Losos, E. (1998). Quantifying Threats to Imperiled Species in the United States. Bioscience, 607-615.

Worthington, T., Tisdale, J., Kemp, P., Williams, I., \& Osborne, P. (2010). Public and stakeholder attitudes to the reintroduction of the burbot, Lota lota. Fisheries Management and Ecology, 465-472. 
CHAPTER 2

\section{RECREATIONAL ANGLER PERSPECTIVES OF MERCURY ADVISORIES}




\section{Introduction}

Since early in human history, fish protein has been a diet staple worldwide (Brooks \& Potts, 2010). Lakes, streams and waterways have provided dependable food sources for millennia, in addition to contributing to cultural traditions, trade and recreation. In 2009, the United Nation's Fishing and Aquaculture Organization estimated that over 10.1 million tons of fish were captured in inland waters $(11 \%$ of global fish capture) and supported livelihoods for hundreds of millions people globally (FAO, 2010). The high quality of fish protein can have positive effects on cardiovascular health and prenatal development (Driscoll, Sorensen, \& Deerhake, 2012). However, there can also be potential health risks in consuming fish due to environmental pollution related to industrial, extractive and agricultural activities (Stow et al. 1995, Agusa et al. 2007, Ye et al. 2008, Ebrahimi \& Taherianfard, 2011, Kim et al. 2011). Mercury (Hg) is one of the most toxic and studied pollutants found in fish, ranked the third highest priority toxic substance (after Arsenic and Lead) by the United States Agency for Toxic Substances and Disease Registry (ATSDR) because of its serious toxicity effects and the potential for human exposure (ASTDR, 2013).

Studies of exposure to high levels of Methyl Mercury (MeHg), the most toxic form of $\mathrm{Hg}$, have found that the central nervous system is most vulnerable in adults (Diez \& Whitacre, 2009). Ataxia, paresthesia, facial paralysis and loss of muscle coordination are common symptoms of $\mathrm{Hg}$ poisoning (Grandjean et al. 2010). Cardiovascular health problems such as hypertension and myocardial infarction have also been found to be associated to $\mathrm{MeHg}$ exposure (Roman et al. 2011). High levels of toxicity can cause 
reproductive failure, which has been observed in wildlife and humans alike (Tan et al. 2009). Low exposure levels of MeHg have also been associated with impaired prenatal and neonatal brain development and low birth weight (Grandjean et al. 1997, 2010, Suzuki et al. 2010, Marques et al. 2013). Thus, government agencies are compelled to warn the public on potential $\mathrm{Hg}$ toxicity.

Past applications of $\mathrm{Hg}$ in medicine, as an agricultural fungicide, and as an industrial catalyst have detrimental effects on exposed human populations (Grandjean et al. 2010).Today, exposure to dental amalgams and consumption of contaminated piscivorous fish are the most common sources of MeHg exposure (Diez \& Whitacre, 2009). Although use of $\mathrm{Hg}$ has been reduced in North America by technological improvements and air pollution regulations (Pirrone et al. 1998), major inputs of Hg into our environment continue to pollute even remote freshwater ecosystems (Fitzgerald et al. 1998).

Florida is among the hotspots for wet (through precipitation) and dry (atmosphere-to-surface in dry weather) Hg deposition in the United States (Fulkerson, 2007, Gu, Axelrad, \& Lange, 2012), and high MeHg levels are found in freshwater, periphyton, grass shrimp, and fish in Everglades Water Conservation Areas (WCAs) and Everglades National Park (Cleckner, 1998, Hurley et al. 1998). Elemental Hg is converted into a readily available organic $\mathrm{MeHg}$ by sulfur reducing bacteria, and then it bioaccumulates in aquatic food webs (Cleckner, et al., 1999). These types of bacteria, and elevated concentrations of sulfur and phosphorus from the Everglades Agricultural Area, facilitate seasonal fluxes of MeHg conversion in the WCAs of the Florida Everglades 
(Liu, et al., 2008). The Environmental Protection Agency (EPA) recommends a limit of two eight-ounce meals per month for fish with tissue concentrations excedding $0.3 \mu \mathrm{g} / \mathrm{Hg} / \mathrm{kg}$ (EPA, 2004). Many sport fish in the Everglades, such as the largemouth bass and sunfishes (Lepomis spp) contain high levels of MeHg in their muscle tissue that exceed this concentration (Axelrad, 2007). The Florida Department of Health first issued fish consumption advisories for WCAs in 1989 to promote awareness to anglers that consumption of regional freshwater fish may exceed the safe EPA MeHg dose of $0.1 \mu \mathrm{g} / \mathrm{kg}$ body weight/day (FDEP, 2013). In 2011, all adults, pregnant women and children, due to unsafe MeHg levels, were issued a 'DO NOT EAT' advisory for largemouth bass over 14 inches in length caught from the L-29 canal or WCA-3, within the footprint and relevant time period of this study. 'Over the past decade, the median $\mathrm{Hg}$ concentrations in largemouth bass have not declined and have averaged twice the US EPA's recommended human health criterion for fish consumption (0.3ppm) (FDEP, 2013) ${ }^{\prime}$

The EPA's health advisory for Hg provides a general guideline for consumption of non-commercial fish in the US. However, states, territories and native tribes are primarily responsible for providing residents with advisories for non-commercial fish species. Tan (2011) found that state agencies in the US have varying success in communicating guidelines to recreational anglers and that awareness of mercury advisories and adherence to them is low among non-English speaking, minority groups and women residing with anglers. Advisories may be ineffective when the public suspects biases from the producers of the information or due to complicated dosage and 
portion terminology (Oken \& Choi, 2012). Recreational anglers are believed to be at higher risk of $\mathrm{Hg}$ exposure than non-anglers because of increased exposure when they consume regionally caught fish in addition to commercial fish (Lincoln, 2011). A survey in Louisiana showed that fish consumption was high among recreational anglers and hair samples tested high in $\mathrm{Hg}$ content (median $0.81 \mu \mathrm{g} / \mathrm{g}$ ), with $38 \%$ exceeding, and 13\% doubling the EPA recommended limit of $0.1 \mu \mathrm{g} / \mathrm{kg} /$ day (Lincoln, 2011).

A survey of Everglades recreational anglers by Fleming (1995) found a majority were aware of $\mathrm{Hg}$ advisories, but they were also unresponsive to the advisories in their consumption habits. Building evidence of the negative human health impacts caused by $\mathrm{Hg}$ and ongoing monitoring of high MeHg levels in WCAs is a cause for concern for recreational anglers who consume fish from the area regularly. It is not known if anglers are now more aware or have decreased consumption of fish, since Fleming's study in 1995. I used a personal semi-structured survey of recreational anglers in the Florida Everglades to examine compliance of fish consumption advisories. Here, I focused on addressing awareness and attitudes towards fish consumption advisories across angler types (canal bank vs boat) and as a function of the social demographic structure of the recreational angler population. I expected that a majority of anglers would be unaware of the presence of $\mathrm{Hg}$ consumption advisories in these locations due to the absence of posted advisories, and therefor awareness decreased since the previous study. I expected that compliance with advisories varies among angler types, age groups, income levels, household sizes and level of education achieved. I also hypothesize that anglers support management decisions that decrease $\mathrm{Hg}$ and improve water quality. 


\subsection{Methods}

\subsection{Sample selection and survey design}

This study was conducted through on-site semi-structured surveys that were pretested with the same recreational angler population at the study sites. Potential participants were asked if they fished at the location, if they were 18 years of age or older, and if they would be willing to participate in a short non-identifying survey, and selected if they answered affirmatively to all three questions. Anglers were also asked for consent to make an audio recording of the survey for quality control, and often agreed. Interviews typically took 10 minutes to complete. The same anglers were frequently encountered but were only interviewed once. Approximately 5\% of anglers encountered refused the survey, primarily because they were focused on catching fish or because they came to be alone. Interviews were conducted in English or Spanish, depending on the angler's preference. After the interview was complete, participants were given a copy of the most recent Fish Consumption Advisories (FCAs) for WCA-3 and the L-29 canal, printed from the Florida Department of Health website. All interviews were conducted by the same individual.

The survey (Appendix 1) was constructed of four sections. The first section was composed of a series of $14-19$ questions (depending on responses to questions 2, 5, 7, \& 16) concerning history at the location, fishing practices, angler motivations, fishing preferences and consumption habits. The second section was comprised of 2-4 questions (depending on responses) concerning the angler's awareness of FCAs and the effects they had on consumption of fish from the area. The third section was comprised of 2 to 4 questions (depending on season) soliciting the angler's level of agreement with a series of 
statements concerning the reducing $\mathrm{Hg}$ and improving water quality, prior to and after an informational brief on the topic. The survey ended with two questions concerning the effectiveness and usefulness of FCAs and asking the angler to complete a card requesting basic demographic information to analyze sample and subsample demographic characteristics (Table 1).

\subsection{Study area and survey effort}

The present day Everglades fishery is comprised of an intricately crafted drainage system, a web of canals that provides access to a thriving sport fishery for recreational anglers that includes the native largemouth bass (Gibson, 2006, FWC, 2013). Two popular canal fishing locations were targeted for the angler survey bordering the highly managed Water Conservation Area-3A (WCA-3A), in the central Everglades (Figure 1). Man-made canals and natural marshes in this region constitute part of a Wildlife Management Area (WMA) which allows fishing, hunting, and other outdoor recreation activities while sustaining habitat for native wildlife (FWC, 2013), and is managed by the FWC, in cooperation with the South Florida Water Management District (SFWMD) which operates the canals, levees, water control structures and access roads. Location 1 is a twenty-two mile stretch of canal bank running parallel to the L-29 canal, and Tamiami Trail (US 41), which serves as the main corridor between the east and west coasts of south Florida. The canal also compartmentalizes this region of the Everglades, separating WCA-3A to the north and Everglades National Park (ENP) to the south. Location 2 is Everglades Holiday Park west of Fort Lauderdale, Florida. This is an iconic public recreational area, complete with an airboat tour company and alligator wrestling show, previously leased from Broward County by the FWC, and designated a county park in 
2013. The location was chosen because of its four public boat ramps which provide access to the L-67A canal, one of the best bass angling locations in the state of Florida (FWC, 2013), and it connects to the L-29 canal at the southern end. These locations 1 and 2 were chosen because of the high volume of anglers who fish from the canal levees and from boats (respectively). The survey was conducted year-round from May $6^{\text {th }}, 2012$ to May $4^{\text {th }}, 2013$ and effort was allocated into 13 consecutive 28 -day periods ( 8 wet season periods and 5 dry season periods, Table 2). Each dry season period consisted of three week days and two weekend days (non-holiday) of sampling. To compensate for the lower number of respondents in the wet season when angling effort is lower (B. Moody pers. comm.) the number of wet season survey days was doubled to six week days and four weekend days per period. Every survey day had a morning shift between 8:00 am and 12:00 pm and an afternoon shift from 2:00 pm to 6:00 pm. Study locations alternated within the day, and starting locations alternated between days (within separate week day and weekend day sample framework) to allocate equal sampling effort spatially and temporally. Scheduled survey days were at times cancelled due to poor weather conditions. Bank anglers were recruited at location 1 (L-29 canal) by visually scanning canal banks from a vehicle and approaching everyone fishing. Boat anglers at location 2 (Holiday Park) were approached at boat ramps after and before returning from their fishing trips.

\subsection{Data analyses}

I used a backwards stepwise logistic regression to examine how independent variables such as anglers' characteristics and demographic traits can predict angler awareness of the mercury advisories for all respondents and each angler type 
independently (Table 8). For each categorical variable, levels of increasing education, income, age group, household size and distance were coded to be compared to a reference level (the first level) of the variable (simple coding). This is similar to dummy coding, in which a $0 / 1$ categorical variable (dummy variable) is compared. A small number of anglers opted not to complete the demographic card in its entirety, leaving blank values for Total household income $(n=25)$, Zip code $(n=16)$ and Education $(n=12)$. Deleting cases with missing values may cause bias (Scheffer, 2002). A common statistical software method used to avoid losing valuable information is to impute the data with the mean or mode (Scheffer, 2002). Missing continuous data for the variables Age, Household size, and Distance (calculated from zipcode, using GIS 10.0) were imputed by taking the mean of the sample variable. Missing categorical data such as Total household income and Education were imputed by taking the modes of the sample variables. The Hosmer-Lemeshow test of goodness of fit was applied to the resulting logistic regression models.

Summary statistics for average meals per month were calculated only from individuals who had kept a fish in the last year. Summary statistics for opinions about FCAs were calculated only from individuals who were aware of them. Responses to questions soliciting opinions on mercury advisories were scored as either no opinion, only positive, only negative, and positive and negative. Opinions about $\mathrm{Hg}$ advisories were classified into one or more distinct categories that encompassed the variety of responses received. Categorical data among sample subgroups were compared using Pearson's $\chi^{2}$ tests. I also wanted to see if anglers thought it was important to improve water quality and decrease $\mathrm{Hg}$ for themselves or for future generations through questions 
Table 8: Variables used in regression analyses for awareness of mercury advisories

\begin{tabular}{|c|c|c|}
\hline Characteristic & Description & Variable type \\
\hline Experience & Years & Continuous \\
\hline Frequency & $\begin{array}{l}\text { Average number of fishing days } \\
\text { per month }\end{array}$ & Continuous \\
\hline Fish for recreation & Confirmed or otherwise & Categorical \\
\hline Fish for sport & Confirmed or otherwise & Categorical \\
\hline Fish for food & Confirmed or otherwise & Categorical \\
\hline \multirow[t]{4}{*}{ Distance from home } & Less than 10 miles & Categorical \\
\hline & Between 10 and 20 miles & \\
\hline & Between 20 and 30 miles & \\
\hline & More than 30 miles & \\
\hline \multirow[t]{2}{*}{ Gender } & Male & Categorical \\
\hline & Female & \\
\hline \multirow[t]{4}{*}{ Age group } & $18-37$ & Categorical \\
\hline & $38-47$ & \\
\hline & $48-57$ & \\
\hline & 58 and older & \\
\hline \multirow[t]{4}{*}{ Education } & Less than high school or GED & Categorical \\
\hline & High school or GED & \\
\hline & Some college & \\
\hline & Bachelor's degree or higher & \\
\hline \multirow[t]{4}{*}{ Total household income } & Less than $\$ 20,000$ & Categorical \\
\hline & $\$ 20,000-\$ 39,999$ & \\
\hline & $\$ 40,000-\$ 59,999$ & \\
\hline & $\$ 60,000$ or more & \\
\hline \multirow[t]{3}{*}{ Household size } & $1-2$ & Categorical \\
\hline & $3-4$ & \\
\hline & 5 or more & \\
\hline \multirow[t]{2}{*}{ Angler type } & Canal bank & Categorical \\
\hline & Boat & \\
\hline Fishing club membership & Confirmed or otherwise & Categorical \\
\hline Meals & $\begin{array}{l}\text { Average number of fish meals } \\
\text { from location per month }\end{array}$ & Continuous \\
\hline
\end{tabular}


requiring the respondent to choose their level of agreement with a statement using a 5 point rating scale with options of strongly agree $(=5)$, somewhat agree $(=4)$, neutral $(=3)$, somewhat disagree $(=2)$ and strongly disagree $(=1)$. The Mann-Whitney U test was performed to test for a difference in distribution of responses 1) between each question, to compare present and future use values, 2) between seasons to find if hearing an informational brief influenced strength in agreement, and 3) between angler types. All analyses were completed using IBM SPSS Statistics for Windows, version 20.0.

\section{Results}

\subsection{Angler consumption habits}

Of the 355 anglers surveyed, 13.5\% were fishing at the location for the first time. The mean years of Experience at the location and mean fishing Frequency for the remaining $86.5 \%$ of the sample are shown in Table 9. Of the 307 anglers who had at least one month of fishing experience, $41.4 \%$ had consumed fish from the area at least once in the past year (average number of meals per month is also described in Table 9). Of those 127 anglers, $73.2 \%$ were aware there were mercury advisories for fish in the region. Of the same 127 anglers, $45.7 \%$ stated that the mercury advisories did not cause them to eat less fish. Combining this percentage with the percentage of anglers who were unaware of the advisories, $72.5 \%$ of anglers who consumed fish from the area in the past year did not consume less fish because of the advisories.

Of the 355 anglers surveyed, 21.7\% were fishing to consume their catch. Canal bank anglers chose for food as a reason for fishing that day at a frequency of $26.7 \%$, which was higher than the $12.7 \%$ of boat anglers $\left(\chi^{2}=9.298, d f=1, p=0.002\right)$. Also $26.5 \%$ of anglers expressed that their target fish species preferences were driven by 
Table 9: Fishing and consumption habits of anglers

\begin{tabular}{lccc}
\hline & $\begin{array}{c}\text { All } \\
\text { respondents }\end{array}$ & $\begin{array}{c}\text { Canal bank } \\
\text { anglers }\end{array}$ & $\begin{array}{c}\text { Boat } \\
\text { anglers }\end{array}$ \\
\hline Years of experience & $19.5 \pm 17.0$ & $17.9 \pm 18.5$ & $\begin{array}{c}21.8 \pm \\
14.3\end{array}$ \\
$n=307$ & $(0.08-75)$ & $(0.08-75)$ & $(.08-51)$ \\
Average days per month & $2.8 \pm 3.4$ & $2.7 \pm 3.2$ & $3.1 \pm 3.6$ \\
$n=307$ & $(0.03-20)$ & $(0.03-20)$ & $(0.08-20)$ \\
Average meals per month & $1.6 \pm 2.1$ & $1.8 \pm 2.4$ & $1.1 \pm 1.3$ \\
$n=127$ & $(0.08-12)$ & $(0.08-12)$ & $(0.08-5)$
\end{tabular}

(range) 
consumption preferences (because I like to eat them), but the frequency of this response did not vary between angler types $\left(\chi^{2}=3.427, d f=1, p=0.064\right)$.

Of the anglers who were not fishing at the location for the first time, $49.2 \%$ have kept some part of their catch in the last year for consumption. The majority ate their catch themselves (45.6\%), while 6.8\% gave their catch to others. Fewer boat anglers $(35.2 \%)$ kept their catch than canal bank anglers $\left(58.4 \%, \chi^{2}=15.740, d f=1, p<0.001\right)$ and also fewer boat anglers (33.6\%) ate their catch $\left(53.5 \%, \chi^{2}=11.745, d f=1, p=0.001\right)$. Canal bank anglers gave their catch to others more frequently than boat anglers, $9.7 \%$ to $2.5 \%$ $\left(\chi^{2}=6.099, d f=1, p=0.014\right)$. Of the anglers that kept their catch $(\mathrm{n}=151), 45.0 \%$ ate their fish at least once a month. Of canal bank anglers, $49.1 \%$ ate their fish once or more per month compared to $34.9 \%$ of boat anglers. The Mann-Whitney U-test determined there is a significant difference in the average number of meals of fish eaten per month (Meals) across angler groups $(p=0.034)$.

\subsection{Angler awareness}

A majority of the anglers sampled, $68.7 \%(n=355)$, answered yes when asked if they were aware of the presence of mercury advisories for fish in the region. After adjusting for other variables in the logistic regression model, advisory awareness was significantly associated with boat anglers, angles over 47 years of age, Distance, some income levels and Frequency (Table 10). Boat anglers were 5.9 times as likely to be aware of mercury advisories as canal bank anglers $\left(\chi^{2}=33.256, d f=1, p<0.001\right)$. Anglers 58 and older were 3.9 times as likely to be aware of mercury advisories as anglers between 18 and 37 years old. Anglers living less than 10 miles from the fishing location were 3 times as likely to be aware as angler living more than 30 miles away. For 
Table 10: Logistic regression model for mercury advisory awareness among all sample anglers

\begin{tabular}{|c|c|c|c|c|}
\hline Characteristic & $\beta$ & Odds Ratio & $\mathrm{CI}$ & $p$-value \\
\hline \multicolumn{5}{|l|}{ Angler type } \\
\hline Canal bank & \multicolumn{3}{|c|}{ Reference } & \\
\hline Boat & 1.77 & 5.9 & $2.9-11$ & $<0.001$ \\
\hline \multicolumn{5}{|l|}{ Frequency } \\
\hline (Average trips/month) & 0.208 & 1.2 & $1.1-1.4$ & 0.001 \\
\hline \multicolumn{5}{|l|}{ Age } \\
\hline $18-37$ & \multicolumn{3}{|c|}{ Reference } & 0.003 \\
\hline $38-47$ & 0.575 & 1.8 & $0.87-3.6$ & 0.1 \\
\hline $48-57$ & 0.732 & 1.1 & $1.0-4.3$ & 0.05 \\
\hline 58 and older & 1.37 & 3.9 & $1.9-8.1$ & $<0.001$ \\
\hline \multicolumn{5}{|l|}{ Distance } \\
\hline More than 30 miles & \multicolumn{3}{|c|}{ Reference } & 0.07 \\
\hline 20-30 miles & 1.22 & 3.4 & $1.2-9.3$ & 0.02 \\
\hline 10-20 miles & 0.82 & 2.3 & $0.96-5.4$ & 0.06 \\
\hline Less than 10 miles & 1.1 & 3.0 & $1.2-7.7$ & 0.02 \\
\hline \multicolumn{5}{|l|}{ Household Income } \\
\hline Less than $\$ 20,000$ & \multicolumn{3}{|c|}{ Reference } & 0.08 \\
\hline$\$ 20,000-\$ 39,999$ & 0.274 & 1.3 & $0.62-2.8$ & 0.5 \\
\hline$\$ 40,000-\$ 59,999$ & 0.931 & 2.5 & $1.1-5.8$ & 0.03 \\
\hline$\$ 60,000$ or more & -0.018 & 0.98 & $0.48-2.0$ & 0.9 \\
\hline
\end{tabular}


every one unit increase in Frequency, the probability of being aware of the advisories increased by $20 \%$. The Hosmer-Lemeshow goodness of fit test determined that there is no difference between the model-predicted and observed values $\left(\chi^{2}=4.134, d f=8, p=\right.$ 0.845).

Of boat anglers interviewed, $88.1 \%$ claimed to be aware of the advisories in comparison to the $58.5 \%$ of canal bank anglers. When analyzing awareness separately for boat and canal bank anglers, I found they have differing predictor variables. After adjusting for other variables in the logistic regression model, advisory awareness among canal bank anglers was significantly associated with Frequency, Age and Distance (Table 11). Canal bank anglers 58 years of age and older are 3.4 times as likely to be aware of mercury advisories as canal bank anglers between 18 and 37 years old. Anglers living less than 10 miles away were 3.8 times as likely to be aware as anglers who live more than 30 miles away. The Hosmer-Lemeshow goodness of fit test determined that there is no difference between the model-predicted and observed values $\left(\chi^{2}=3.057, d f=8, p=\right.$ $0.931)$.

After adjusting for other variables in the logistic regression model for awareness of boat anglers, no significant predictor of awareness was found at an alpha of 0.05 .

\subsection{Perception of the importance of improved water quality}

A majority of anglers strongly agreed with both statements concerning the importance of improving water quality and decreasing mercury in the environment. The most common response to statement one (Management decisions that will decrease mercury and improve water quality are important to me), was strongly agree $(85.7 \%)$ 
Table 11: Logistic regression model for mercury advisory awareness among canal bank anglers

\begin{tabular}{lcccc}
\hline Characteristic & $\beta$ & Odds Ratio & CI & $p$-value \\
\hline & & & & \\
Frequency & & & & \\
(Average trips/month) & 0.24 & 1.3 & $1.1-1.4$ & $\mathbf{0 . 0 0 1}$ \\
Age & & & & \\
$18-37$ & & Reference & & $\mathbf{0 . 0 2}$ \\
$38-47$ & 0.45 & 1.6 & $0.87-3.6$ & 0.3 \\
$48-57$ & 0.75 & 2.1 & $1.0-4.3$ & 0.08 \\
58 and older & 1.2 & 3.4 & $1.9-8.1$ & $\mathbf{0 . 0 0 2}$ \\
Distance & & & & \\
More than 30 miles & & Reference & & $\mathbf{0 . 0 5}$ \\
20-30 miles & 1.5 & 4.3 & $1.3-14$ & $\mathbf{0 . 0 2}$ \\
10-20 miles & 0.85 & 2.3 & $0.85-6.4$ & 0.1 \\
Less than 10 miles & 1.3 & 3.8 & $1.3-10$ & $\mathbf{0 . 0 1}$ \\
p values $<0.05$ in bold & & & &
\end{tabular}


followed by somewhat agree (10.3\%), neutral (2.4\%) and somewhat disagree $(0.8 \%)$ and strongly disagree $(0.8 \%)$. The most common response to statement two (It is important to me to improve water quality and decrease mercury for future generations) was strongly agree (95.6\%) followed by somewhat agree (3.5\%) and neutral (0.9\%). A significantly higher percentage of the sample strongly agreed with statement two than with statement one $\left(\chi^{2}=20.751, d f=1, p<0.05\right)$. There was no significant difference between the distribution of Likert scale responses to statement one $(U=15,093, p=0.711)$ and statement two $(\mathrm{U}=15,018, p=0.383)$ between wet season anglers $(n=203)$ asked after the informational brief and dry season anglers $(n=141)$ asked before the brief. There was no significant difference in the distribution of Likert scale responses to statement one (U $=4,117, p=0.390)$ or statement two $(\mathrm{U}=4,287, p=0.734)$ across angler types.

\subsection{Angler perspectives of mercury advisories}

Anglers who are aware of the mercury advisories keep their catch equally as frequently as anglers who are unaware of them, $46.7 \%$ to $47.7 \%\left(\chi^{2}=0.032, d f=1, p=\right.$ 0.857). When asked 'why do you release the fish you catch?', boat anglers gave a response categorized as 'health risks' $23 \%$ of the time compared to only $10 \%$ of canal bank anglers $\left(n=355, \chi^{2}=11.9, p<0.01\right)$. When asked, 'Do you think you would choose fishing spots differently if you knew where there was better water quality?', angler types differed in their responses. Canal bank anglers answered yes $83 \%$ of the time compared to only $55 \%$ of boat anglers $\left(n=354, \chi^{2}=32.5, p<0.001\right)$. Angler types also differed in their opinions when asked, 'Do you believe that people are being informed 
enough on the dangers of consuming mercury?' Boat anglers responded yes $41 \%$ of the time compared to only $19 \%$ by canal bank anglers $\left(n=355, \chi^{2}=19.8, p<0.001\right)$.

\section{Discussion}

The percentage of boat anglers who consumed fish was significantly less than the percentage of canal bank anglers (34.9\% to $53.7 \%$ ). The $31 \%$ of anglers who were not aware of advisories $(\mathrm{n}=111)$ kept fish as often as those who were aware, $47.7 \%$ to $46.7 \%$ respectively. Within the group of anglers who were unaware, boat anglers $(n=15)$ were nearly as likely to keep their catch as canal bank anglers $(n=96), 53.3 \%$ to $46.9 \%$ respectively. The strongest predictor of awareness was the variable Angler type. Canal bank anglers were 5.85 times less likely to be aware of the consumption advisories than boat anglers. Age was a significant predictor of awareness for the sample. Canal bank anglers of older age groups and those who lived nearby and fished there more frequently were more aware. Independent regression analyses of angler types did not show higher income groups to be more aware of advisories than lower income groups. There was an association between total household income and angler type, with more boat anglers in

the upper income levels $\left(\chi^{2}=58.938, d f=3, p<0.001\right)$. The majority of the sample held the perspective that the public is not informed enough on mercury advisories. A higher percentage of boat anglers than canal bank anglers felt there was sufficient information available concerning mercury consumption advisories ( $41 \%$ to $19 \%)$ and less boat anglers said they would choose fishing locations differently if they knew where there was better water quality ( $55 \%$ to $83 \%)$. 
Fleming's study in 1995 found that $71.0 \%$ of Everglades recreational anglers who regularly consumed fish from the area (at least once per month) were aware of local FCAs for $\mathrm{Hg}$ and of those, $74 \%$ did not change their fish consumption habits. Of the comparable segment from this study $(n=69), 69.6 \%$ were aware, showing no significant difference in awareness from the previous study $\left(\chi^{2}=0.0148, \mathrm{df}=1, p=0.903\right)$. There was also no significant difference between these studies in the percentage of anglers who were unresponsive in their consumption habits $(64.6 \%$ to $74.0 \%)\left(\chi^{2}=1.82, d f=1, p=\right.$ 0.177). Logistic stepwise regression found lower household income to be associated with a lack of awareness in both studies. Awareness of consumption advisories has also been found to significantly lower in demographic groups making less than $\$ 20,000$ in other studies (LePrevost, et al., 2013, Burger, 1998).

A study by LeProvost (2013) in North Carolina also found that shoreline anglers were significantly less aware of local consumption advisories than boat anglers. The lack of resources to fish by boat, i.e. income, has also been noted by Beehler (2003) in a study observing low awareness of latino recreational and subsistence anglers who fish from shore and from boat. Higher awareness by boat anglers has been attributed to posted mercury advisory signs at boat ramps and immersion in fishing literature (LePrevost, et al., 2013). Anglers attribute increased awareness to the presence posted signs (Beehler, 2003), however there is variability in the success of posted signs, with higher awareness reported from newspaper, television and other people, and issuance of advisories at the time of license purchase (Katner et al., 2011, Burger, 1998). All locations used in this 
study were without any posted advisories referring to consumption guidelines or mercury content, however a majority of anglers were aware that guidelines existed.

Anglers in my study who consumed fish were also found to be sharing fish with others, which may be putting vulnerable subpopulations at risk. These include pregnant women, women of childbearing age, women who are breastfeeding and children under the age of 15, whose unawareness of health risks may be low. Further, if anglers have negative opinions or doubts about $\mathrm{Hg}$ advisories, they are less likely to correctly convey information to family and friends (Tan M. L., 2011). A majority of aware anglers gave opinions that portrayed consumption advisories in a positive light (88.3\%), yet others gave opinions that were dismissive of the advisories. Anglers may dismiss advisories due to long-held misconceptions about water quality and overall disbelief about the harm contamination may pose to them (Tan M. L., 2011). Advisories that are hard to understand or alarming may also cause defensive individuals to become more guarded and unresponsive to them (Griffin \& Harris, 2011). The minority of boat and canal bank anglers in this study who were aware of the consumption advisories, changed consumption habits very similarly, stating that they consumed less fish because of the advisories, $44.1 \%$ and $43.6 \%$ respectively.

This study provides insight into angler motives to fish, the choices anglers make when consuming their catch and the influence that local fish consumption guidelines have on their eating habits. Awareness of health advisories was primarily related to fishing experience and frequency of visits, in addition to angler type and associated demographic variables. Better communication can be achieved without causing undo concern to 
stakeholders and tourists that want to utilize the fishery. Fishery managers should strive to reach a balance in providing advisories that increase concern in high-risk individuals and decrease over responsiveness in low-risk individuals (Griffin \& Harris, 2011). It is clear that there are a high number of anglers in Everglades canals that consume their catch and are not aware of the fish consumption advisories. Previous studies of the effects of $\mathrm{Hg}$ exposure on fetal and childhood development and studies describing low awareness among non-angler household members, supports the need for better communication of consumption guidelines to the general public. A logical extension of this research would be to ask anglers how they became aware of consumption guidelines and what sources they use to inform themselves. Testing anglers on their ability to perceive meal portion size, can help understand if anglers underestimate portion sizes and therefor their MeHg consumption. Useful knowledge could also be gained by hairmercury content analysis accompanied by commercial and recreational fish consumption data. 


\section{Bibliography}

Agusa, T., Kunito, T., Sudaryanto, A., \& Monorith, I. (2007). Exposure assessment for trace elements from consumption of Marine Fish in Southeast Asia. Environmental Pollution, 766-777.

ASTDR (Agency for Toxic Substance and Disease Registry). (2013, October 2). Priority List of Hazardous Substances. Retrieved from Agency for Toxic Substance and Disease Registry: http://www.atsdr.cdc.gov/spl/

Axelrad Donald M, e. a. (2007). Chapter 3B: Mercury Monitoring, Research and Environmental Assessment in South Florida. Tallahassee: Florida Department of Environmental Protection.

Beehler, G., McGuinness, B., \& Vena, J. (2003). Characterizing Latino Angler's Environmental Risk Perception. Medical Anthropology Quarterly, 99-116.

Brooks, A., \& Potts, R. (2010). What does it mean to be human? A behavioral perspective. Anthronotes, 1-24.

Burger, J. (1998). Fishing and risk along the Savvanah River:Possible Intervention, Part A:Current Issues. Journal of Toxicology and Environmental Health, 405-419.

Cleckner, L. e. (1998). Trophic transfer of methyl mercury in the northern Florida Everglades. Biogeochemistry, 347-361.

Cleckner, L., Gilmour, C., Hurley, J., \& Krabbenhoft, D. (1999). Mercury Methylation in Periphyton of the Florida Everglades. Limnology and Oceanography, 1815-1825.

Diez, S., \& Whitacre, D. (2009). Reviews of Environmental Contamination and Toxicology. Paron, AK: Springer.

Driscoll, C., Han, Y.-J., Chen, C., Evers, D., Lambert, K., Holsen, T., . . Munson, R. (2007). Mercury Contamination in Forest and Freshwater Ecosystems in the Northeastern United States. BioScience, 17-28.

Driscoll, D., Sorensen, A., \& Deerhake, M. (2012). A Multidisciplinary Approach to Promoting Healthy Subsistence Fish Consumption in Culturally Distinct Communities. Health Promotion Practice, 245-251.

Ebrahimi, M., \& Taherianfard, M. (2011). Pathological and Hormal Changes in Freshwater Fishes Due to Exposure to Heavy Metal Pollutants. Water, Air \& Soil Pollution, 47-55. 
Fitzgerald, W., Engstrom, D., Mason, R., \& Nater, E. (1998). The Case for Atmospheric Mercury Contamination in Remote Locations. Environmental Science and Technology, 1-7.

Fleming, L. E., Watkins, S., Kaderman, R., Levin, B., Ayyar, D. R., Bizzio, M., . . Bean, J. A. (1995). Mercury Exposure in Humans Through Food Consumption from the Everglades of Florida. In Mercury as a Global Pollutant (pp. 41-48).

Netherlands: Springer.

Fulkerson, M. e. (2007). Characterizing dry deposition of mercury in urban runoff. Water, Air, Soil Pollution, 21-32.

Grandjean, P., Satoh, H., Murata, K., \& Eto, K. (2010). Adverse Effects of Methylmercury: Environmental Health Research Implications. Environmental Health Perspectives, 1137-1145.

Grandjean, P., Weihe, P., White, R., Debes, F., Araki, S., Yokoyama, K., . . Jorgensen, P. (1997). Cognitive deficit in 7 year-old children with prenatal exposure to mercury. Neurotoxicology and Teratology, 417-428.

Griffin, D., \& Harris, P. (2011). Calibrating the Response to Health Warnings : Limiting Both Overreaction and Underreaction With Self-Affirmation. Psychological Science, 572-578.

Gu, B., Axelrad, D., \& Lange, T. (2012). 2012 South Florida Environmental Report. West Palm Beach, FL: South Florida Water Management District.

Hurley, J., Krabbenhoft, D., Cleckner, L., Olson, M., Aiken, G., \& Rawlick Jr., P. (1998). System controls on the aqueous distribution of mercury in the northern Florida Everglades. Biogeochemistry, 293-310.

Karagas, M., Choi, A., Oken, E., Horvat, M., Schoeny, R., Kamai, E., . . Korrick, S. (2012). Evidence on the Human Health Effects of Low-Level Methylmercury Exposure. Environmental Health Perspectives, 799-806.

Katner, A., Ogunyinka, E., Sun, M.-H., Soileau, S., Lavergne, D., Dugas, D., \& Suffet, M. (2011). Fishing, fish consumption and advisory awareness among Louisiana's recreational fishers. Environmental Research, 1037-1045.

Kim, J.-W., Isobe, T., Chang, K.-H., Amano, A., Maneja, R., Zamora, P., . . Tanabe, S. (2011). Levels and distribution of organophosphorus flame retardants and plasticizers in Fishes from Manilla Bat, the Philippines. Environmental Pollution, 3653-3659.

L. E. Fleming, e. a. (1995). Mercury Exposure in Humans Through Food Consumption from the Everglades in Florida. Water, Air, and Soil Pollution, 41-48. 
LePrevost, C., Gray, K., Hernandez-Pelletier, M., Bouma, B., Arellano, C., \& Cope, G. (2013). Need for Improved Risk Communication of Fish Consumption Advisories to Protect Maternal and Child Health: Influence of Primary Informants. International Journal of Environmental Research and Public Health, 1720-1734.

Lincoln, R. e. (2011). Fish Consumption and Mercury Exposure among Louisiana Recreational Anglers. Environmental Health Perspectives, 245-251.

Liu, G., Cai, Y., Philippi, T., Kalla, P., Scheidt, D., Richards, J., . . Appleby, C. (2008). Distribution of total and methylmercury in different ecosystem compartments in the Everglades: Implications for mercury bioaccumulation. Environmental Pollution, 257-265.

Marques, R., Bernardi, J., Dorea, J., Brandao, K., Bueno, L., Leao, R., \& Malm, O. (2013). Fish consumption during prenancy, mercury transfer, and birth weight along the Madeira River Basin in Amazonia. International Journal of Environmental and Public Health, 2150-2163.

National Wildlife Federation, F. W. (2006). An Unfavorable Tide: Global Warming, Coastal Habitats and Sport Fishing in Florida. National Wildlife Federation.

Oken, E., \& Choi, A. (2012). Which fish should I eat? Perspectives Influencing Fish Consumption Choices. Environmental Health Perspectives, 790-798.

Pirrone, N., Allegraini, I., Keeler, G., Nriagu, J., Rossman, R., \& Robbins, J. (1998). Historical atmospheric mercury emissions and depositions in North America compared to mercury accumulations in sedimentary records. Atmospheric Environment, 929-940.

Roman, H., Walsh, T., Coull, B., Dewailly, E., Guallar, E., Marrien, K., . . Rice, G. (2011). Evaluation of the Cardiovascular Effects of Methylmercury Exposures:Current Evidence Supports Development of a Dose-Response Function for Regulatory Benefits Analysis. Environmental Health Perspectives, 607-614.

Scheffer, J. (2002). Dealing with Missing Data. Res. Lett. Inf. Math. Sci., 153-160.

Stow, C., Carpenter, S., Mandenjian, C., Eby, L., \& Jackson, L. (1995). Fisheries Management to Reduce Contamination Consumption. Bioscience, 752-758.

Suzuki, K., Nakai, K., Sugawara, T., Nakamura, T., Ohba, T., Shimada, M., ... Satoh, H. (2010). Neurobehavioral effects of prenatal exposure to methylmercury and PCBs, and seafoodintake: Neonatal behavioral assessment scale results of Tohoku study of child development. Environmental Research, 699-704.

Tan, M. L. (2011). Communicating Fish Consumption Advisories in California. Risk Analysis, 1095-1105. 
Tan, S., Meiller, J., \& Mahaffey, K. (2009). The Endocrine Effects of Mercury in Humans and Wildlife. Critical Reviews in Toxicology, 228-269.

Wolfe, M., Schwarzbach, S., \& Sulaiman, R. (1998). Effects of Mercury on Wildlife: A Comprehensive Review. Environmental Toxicology and Chemistry, 146-160.

Ye, X., Strynar, M., Nakayama, S., Varns, J., Helfant, L., Lazorchak, J., \& Lindstrom, A. (2008). Perfluorinated compounds in whole fish homogenates from the Ohio, Missouri and Upper Mississippi Rivers, USA. Environmental Pollution, 12271232. 


\section{APPENDIX 1}

\section{Everglades L-29 \& L-67 Canal Angler Survey}

1. How long have you been fishing in these canals?

2. Do you fish on land and from boat here? $\mathrm{Y} / \mathrm{N}$

3. What percentage of time do you fish from land $\%$ and boat $\%$ here?

4. How often do you fish in these canals? (x per week/month/year)

5. So do you fish here all year long? Y/N

6. When do you not fish here?

7. Do you belong to any fishing clubs or organizations? Y/N

8. Which ones?

9. Why do you fish here? You may select more than one of the following options. Would you say...

a) for sightseeing and recreation

b) for sport

c) for food

d) something else

10. Would you say that you could fish in other places that are equally good fishing opportunities? Y/N

11. What type of fishing pole are you using? (cane/spin/cast/fly/jig/wheel)

12. What type of bait do you use? (live/dead/artificial/other)

13. What kind of fish are you targeting today?

14. Which kind of fish do you want to catch the most?

15. Which of these statements best describes why you fish for these particular types of fish? You can have multiple answers.

a. Because they are easy to catch

b. Because I like to eat them

c. Because they are challenging to catch

d. Other(explain)

16. Which ones do you keep?

17. Do you eat them?

18. Which kinds of fish do you release?

19. Why do you release them?

20. Are you aware that many species of fish found here are not from here? $\mathrm{Y} / \mathrm{N}$

21. Have you heard the term native species before? $(\mathrm{Y} / \mathrm{N})$

22. Can you tell me what it means to you? 
23. Have you heard the term nonnative or exotic species before? (Y/N)

24. Can you tell me what it means to you?

25. Have you heard the term invasive species before? $(\mathrm{Y} / \mathrm{N})$

26. Can you tell me what it means to you?

27. What is your opinion of nonnative fish?

Please pick one of these options based on how you feel about the following statements:

28. Management decisions that will benefit the future of native species are important to me.

(Dry season survey only)
a. Strongly agree
b. Somewhat agree
c. Neutral
d. Somewhat disagree
e. Strongly disagree

29. It is important to me to conserve native species for future generations.

(Dry season survey only)
a. Strongly agree
b. Somewhat agree
c. Neutral
d. Somewhat disagree
e. Strongly disagree

I'm going to say four sentences about non-native species to inform you on them:

Nonnative species are not originally from the Everglades and can out-compete native species for food, space and resources. The Everglades is now known to be home to over 24 nonnative fish species. In 1994, nonnatives were reported to be the primary cause of 44 native fish species as having a threatened or endangered species status in the United States, along with causing notable harm to at least 27 other species. For example, largemouth bass is a native species and peacock bass is nonnative.

Please pick one of these options based on how you feel about the following statements:

30. Management decisions that will benefit the future of native species are important to me. (Wet season and dry season survey)
a) Strongly agree
b) Somewhat agree
c) Neutral
d) Somewhat disagree
e) Strongly disagree

31. It is important to me to conserve native species for future generations.

(Wet season and dry season survey) 

a) Strongly agree
b) Somewhat agree
c) Neutral
d) Somewhat disagree
e) Strongly disagree

32. Are you aware of the mercury advisories for this region? Y/N

33. What do you think about the advisories?

34. Do they cause you to eat fewer fish? Y/N

35. How often do you and your household eat fish from this area per week or month?

Please pick one of these options based on how you feel about the following statements:

36. Management decisions that will decrease mercury and improve water quality are important to me. (Dry season only)
a. Strongly agree
b. Somewhat agree
c. Neutral
d. Somewhat disagree
e. Strongly disagree

37. It is important to me to improve water quality and decrease mercury for future generations. (Dry season only)
a. Strongly agree
b. Somewhat agree
c. Neutral
d. Somewhat disagree
e. Strongly disagree

I'm going to say four sentences about mercury poisoning to inform you on it:

Long-term exposure or high dose exposure to mercury can cause gum problems, mental health problems, nervous system damage, and cause birth defects. Mercury levels in the Everglades have tested among the highest in the country. The Florida Department of Health in 2011 advises adults, pregnant women and children to NOT eat any bass over 14 inches in length caught from this area. Monthly and weekly limits are also in effect for other species.

Please pick one of these options based on how you feel about the following statements:

38. Management decisions that will decrease mercury and improve water quality are important to me. (Dry season and wet season)
a) Strongly agree
b) Somewhat agree
c) Neutral 

d) Somewhat disagree
e) Strongly disagree

39. It is important to me to improve water quality and decrease mercury for future generations.

(Dry season and wet season)
a) Strongly agree
b) Somewhat agree
c) Neutral
d) Somewhat disagree
e) Strongly disagree

40. Do you think you would choose fishing spots differently if you knew where there was better water quality? Y/N

41. Do you believe that people are being informed enough on the dangers of consuming mercury? Y/N

42. - 48. Could you please finish the survey by filling out this card? It will be anonymous and confidential.

\begin{tabular}{|l|l|}
\hline Zip code: & $\begin{array}{l}\text { Education level: } \\
\text { a. }\end{array}$ \\
\hline Sex: Male/Female & b. Did not complete high school \\
\hline & c. Some college \\
\hline Age: & d. Bachelor's degree or higher \\
\hline Hous ehold size & Total household income: \\
\hline Adults: & a. Under $\$ 20,000$ \\
\hline Children under $18:$ & b. $\$ 20,000-\$ 39,999$ \\
\hline & c. $\$ 40,000-\$ 59,999$ \\
\hline
\end{tabular}

